\title{
Representing discourse in clausal syntax
}

\section{The ki particle in Pharasiot Greek}

\author{
Metin Bağrıaçık* \\ Ghent University \\ metin.bagriacik@Ugent.be
}

\begin{abstract}
In Pharasiot Greek, an Asia Minor Greek dialect, a certain particle copied from Turkish, $k i$, is employed in a number of seemingly unrelated constructions. Close scrutiny, however, reveals that in each of these constructions, $k i$ is employed as a device geared to influencing the interlocutor's epistemic vigilance. Based on the Cartographic Approach which defends the syntactization of the interpretive domains, I propose that this unique semantics of $k i$ should be represented in the clause structure. Following recent work which advocates the existence of a pragmatic field-Speech Act Phrase (SAP) in particular-above the CP-layer, where discourse and pragmatic roles are mapped onto syntax, I propose that $k i$ is the overt exponent of $\mathrm{SA}^{0}$ and is further endowed with a [+sentience] feature indexing the speaker as the sentient mind. The apparent differences between various construction types which involve $k i$-hence, in which SAP projects - then reduce to whether the [+sentience] feature on $\mathrm{SA}^{0}$ is checked by an internally or externally merging category in Spec, SAP.
\end{abstract}

* I would like to thank Jan Casalicchio, Guglielmo Cinque, Federica Cognola, Lieven Danckaert, Liliane Haegeman, Aslı Göksel, Mark Janse, Io Manolessou, Anna Roussou, Ioanna Sitaridou, the members of GIST - Generative Initiatives in Syntactic Theory-and two anonymous reviewers for their various comments and suggestions on earlier drafts of this paper. My deepest gratitude is to Andreas Konstantinidis, his family and to Konstantinos Kalaitzidis for their hospitality, and to my informants who helped with the data with greater enthusiasm than mine: Despoina K.†, Kathina P., Anastasia I., Eirini P., Evlambia Ch., Georgios S., Georgios K., Leftheris K., Maria S., Nikos T., Prodromos K., Sophia K.†, Theodorakis K., Miranda M., and Maria A. I gratefully acknowledge the Research Foundation-Flanders (Fwo) by which the current research is funded (FWO13/ASP/O1O).

(C) METIN BAĞRIAÇIK, 2017 | DOI: 10.1163/15699846-01702001

This is an open access article distributed under the terms of the prevailing CC-BY-NC license at the time of publication. 


\section{Keywords}

Pharasiot Greek - epistemic vigilance - sentience - syntax - left periphery

One of the most remarkable aspects of the Asia Minor Greek dialects (hereafter AMG) - the dialects of Pontus, Cappadocia, Pharasa and Silli-is the substantial number of lexical, functional and phonological items and/or features that are often (presumed to be) copied into these dialects from Turkish (a.o., Dawkins 1916, 1937). A few of these presumptions with respect to these copied materials and their potential repercussions for the AMG phylogeny have recently been reassessed and/or challenged (see Janse 2001 et seq.; Karatsareas 2011 et seq.; Revithiadou et al. 2006 among many others). Within this line of research, however, what seem to be overlooked are a number of particles of Turkish origin, whose syntactic category (word, clitic or affix) or grammatical function (structural or discourse-driven) in AMG are not readily detectable. The current paper is an attempt to contribute in filling this void by proposing an analysis of one such so-called particle, $k i$, in the dialect of Pharasa (hereafter PhG).

PhG (Varašótika or Aðanalítika) is an AMG dialect which was spoken in modern day Turkey — more specifically in six villages ${ }^{1}$ in the region historically known as 'Pharasa' - until 1923 when the population exchange between Greece and Turkey was enacted by a supplementary protocol to the Treaty of Lausanne. The region of Pharasa, after which the dialect is named, covers what is today the southeast Kayseri Province, specifically the towns of Develi and Yahyalı and their villages, and the northern borderline of Adana Province, specifically the town of Aladağ and its vicinity. Providing the exact number of its speakers before 1923 is rather difficult, if not impossible. Some fragmental information

1 More specifically, in the following villages: Varašós (today Çamlıca, Yahyalı, Kayseri), Čuxúri or Čuxuryúrt (today Çukuryurt, Develi, Kayseri), Afšári or Afšár-köy (today possibly Avşar Mezraası, Şıhlı, Develi), Kiska (today Yaylacık, Develi), Satí (today Satı, Develi), Karatzorén (today Karacaören, Develi), and Garsantí (also known as Fkósi, Posgaraköy or Garatepé; today Mansurlu, Aladağ, Adana) (Dawkins 1916; Papadopoulos 1998, pers. comm.). In Develi (or Everek) itself (which was called E Kostaínos (Ayiós Konstantínos) by the Greeks), there must have been a number of Pharasiot speakers as well. Note that there were numerous other Greek Orthodox villages in the region, albeit Turkophones, such as Tašč́ (Taşçı, Develi), Xoščá (Hoşça, Develi) or Kurumtzá (Gürümze, Feke, Adana). 
(e.g., Kyrillos 1815; Sarantidis 1899; Xenofanis 1896, 1905-1910; Dawkins 1916), suggests that the Orthodox Greek population of the region numbered about 2200 in the late 19th and early 2oth century. According to the Center of Asia Minor Studies, during the population exchange 1848 people were relocated in Greece from Pharasa (Papadopoulos 1998). This number, however, comprises the Turkophone refugees of the region as well. Today the dialect is spoken in a few villages in West and Central Macedonia and in Epirus (Greece) by two firstgeneration and about 23 second-generation refugees. For most speakers, the dialect is a heritage variety, its speakers being bilinguals in (the local dialect of) Modern Greek and PhG. There are various third- or fourth-generation refugees with some (self-proclaimed) degree of knowledge of but with no remarkable competence in the dialect.

The ki particle-as early work on PhG defines it (' $\mu$ óp 10 ', Andriotis 1948: 53) - may optionally follow the verbs of the reporting clause in a quotative construction (cf. Dawkins 1916: 685; Anastasiadis 1976: 259). Consider (1a) with $k i$ and $(\mathrm{lb})$ without $k i:^{2}$

a. Lénkin

$$
\text { da ki, 'Čip pérkin }
$$

mes sa say.IPFV.PST.3SG 3ОВJ KI all take.IPFV.PST.3SG us in.the.ACC šérce tu $[\ldots]$.'

hands.ACC his 'She would say, 'He would take us all in his hands ..."

b. $O$ Xadzefendís le ta sin the.NOM Haciefendi.NOM say.IPFV.NPST.3SG 3OBJ to.the.ACC epé mu, 'Si títi dáraksis ta aúča?' grandmother.ACC my you.NOM why muddle.PFV.PST 3 OBJ thus 'Haciefendi says to my grandmother, 'Why did you meddle it this way?'

2 The terms quotative construction, reporting clause and quote are due to de Vries (2006). Reporting clause refers to the (matrix) clause which hosts the verb introducing the reported direct speech. The reported part will simply be referred to as quote. PhG examples are presented in broad phonetic transcription. The abbreviations employed throughout the article are as follows: $\mathrm{ACC}=$ accusative, $\mathrm{AOR}=$ aorist, $\mathrm{COM}=$ comitative, $\mathrm{CONTR}=$ contrastive marker, $\mathrm{DAT}$ = dative, $\mathrm{EV}$ = evidential, FUT = future, FUT.DEF = definite future marker, FUT.INDEF = indefinite future marker, GEN = genitive, HORT $=$ hortative, $\mathrm{IMP}=$ imperative, INF $=$ infinitive, INTERJ = interjection, IPFV = imperfective, LOC = locative, NOM = nominative, NPST $=$ nonpast, $\mathrm{OBJ}=$ direct $/$ indirect object clitic, $\mathrm{PART}=$ particle, $\mathrm{PST}=$ past tense, $\mathrm{PL}=$ plural, $\mathrm{POSS}$ $=$ possessive, $\mathrm{OPT}=$ optative, $\mathrm{PROG}=$ progressive, $\mathrm{SG}=$ singular, $\mathrm{SUBJ}=$ subjunctive, $\mathrm{VOC}=$ vocative, $1 / 2 / 3=$ first $/$ second $/$ third person. 
Beside its virtually optional occurrence before quotes, the particle $k i$ is also employed in a wide range of constructions which, prima facie, seem not to be easily relatable to one another. In these constructions, it resembles a complementizer, a coordinator or a clause-final emphatic particle. The employment of $k i$ in such apparently unrelated constructions evokes the possibility that $k i$ is either a multifunctional morpheme or there are a number of distinct ki's in PhG. In this paper, I will discard these possibilities and will argue that in all these ostensibly unrelated constructions, $k i$ is a morpheme employed by the speaker to influence the hearer's epistemic vigilance; to display her competence, benevolence and trustworthiness to the hearer (cf. Wilson 2011; hereafter the 'speaker' will be referred to as 'she/her' and the hearer will be referred to as 'he/him'). Following the Cartographic approach to the left periphery (a.o., Rizzi 1997 et seq.), which defends the syntactization of the interpretive domains, I will argue that this unique semantics of $k i$ should be mapped onto syntax in a dedicated functional projection where discourse and pragmatic roles are encoded as a predicative structure encoding the conversational set-up (i.e., the speaker, the hearer and the power relations between the two throughout the conversation). Based on recent work by Hill (2007, 2010, 2012); Miyagawa (2012); Haegeman and Hill (2013) and Haegeman (2014) (whose analysis is ultimately built on Speas and Tenny 2003), I identify this functional projection as Speech Act Phrase (SAP) above the CP-layer and further argue that $k i$ is a functional element merged in $\mathrm{SA}^{0}$. SAP bears functional features compatible with evaluative, evidential or epistemic features, and it is the functional projection where the pragmatic features of sentience (also known as 'subjectivity' or 'experincer-hood') roles, especially the speaker role, are encoded. The different construction types then derive by whether the [+ sentience] feature on $\mathrm{SA}^{0}$ is checked by an internally or externally merged category in Spec,SAP. The account proposed here not only captures the unique semantic import of $k i$ in each construction type, but it also explains certain structural peculiarities of each construction, as well as why $k i$ seems to behave like a coordinator, a complementizer or a clause-final emphatic particle in different construction types.

The claims and proposals are based on synchronic data from the dialect, collected between 2013-2016 in two villages in Northern Greece (Vathylakkos, Kozani and Platy, Imathia) from fifteen speakers in sum (two first- and thirteen second-generation refugees) who are originally from three distinct villages of the Pharasa region (Varašós, Čuxúri and Afśári). The overall data were first extracted from 11-hour-recordings that were made in the aforementioned time span and were elicited further via questionnaires including 175 items (open-ended questions, translation tasks and Likert-scale questions) which 
were distributed to the speakers in two steps orally. Even though almost all the construction types to be discussed throughout are observed in written corpora as well (written between late 19th century and mid-2oth century), no diachronic discussion of these will be provided since no subtle grammatical judgments can be provided for the data in the texts. Relevant examples from written sources, however, will be provided in footnotes for the interested reader.

The layout of the article is as follows: In section 2, I briefly present each kind of constructions in which $k i$ is employed. In section 3 , I provide the analysis sketched above. Particularly, in section 3.1, I provide the theoretical assumptions adopted in the following analysis. Based on these assumptions, in section 3.2 I argue that $k i$ should be located higher than the CP-field, and by providing evidence from a certain construction type, I identify its position as the head position of SAP. Sections $3 \cdot 3-3 \cdot 4$ extend the analysis further to the remaining construction types, which, under the current approach, should be treated uniformly. Section 4 concludes.

\section{Ki environments}

\subsection{Quotative constructions}

The ostensible optionality of $k i$ in quotative constructions (cf. (1) above) is not structurally conditioned. For instance, its occurrence does not depend on the position of the quote; the quote can follow (1a), precede (2a) or be wrapped around the reporting clause $(2 b)$ :
(2) a. 'Pítak
ta,' le
ta ki.
send.IMP.2SG 3OBJ SAy.IPFV.NPST.3SG 3OBJ KI
"Send it', says he.'

b. 'Ánna,' le

ta ki, 'típus čú ksa.'

no say.IPFV.NPST.3SG 3OBJ KI nothing not hear.PFV.PST.1SG

"No', says he, 'I didn't hear anything."'

Nor is the occurrence of $k i$ conditioned by a post-verbal constituent in the reporting clause or lack thereof. In (1a) and (2), no constituent follows the reporting verb, and $k i$ is adjacent to the verb + clitic. In (3a), on the other hand, the subject of the reporting clause-o tatás tu 'his father'-occurs between the verb + clitic and $k i$. This example also suggests that $k i$ does not have to be strictly adjacent to the verb(+ clitic): 
(3) a. Le ta o tatás tu ki, 'Naátara say.IPFV.NPST.3SG 3OBJ the.NOM father.NOM his KI how much irévis na mi ta ðos?' want.IPFV.NPST.2SG NA 1SG.OBJ 3OBJ give.PFV.NPST.2SG 'His father says, 'how much [money] do you want to sell it to me?'

Moreover, some constituent of the reporting clause can also follow ki. In (3b) below, for example, the subject of the reporting clause-to kortsókku'the little girl'-follows ki:

b. $[\ldots]$ če ipin da ki to kortsókku, 'A and say.PFV.PST.3SG 3OBJ KI the.NOM little girl.NOM mi páris [...]'

FUT.DEF 1SG.OBJ take.PFV.NPST.2SG

'... and the little girl said, 'You will marry me ..."

The word order facts in quotative constructions can be schematically represented as in (4). Ki is always in a position following the verb (and its associate clitics if there are any) of the reporting clause, yet it is not immediately adjacent to the verb, nor does it have to be in absolute clause-final position; any constituent of the reporting clause can occur both between the veb(+clitic) and $k i$, and in a position following $k i:^{3}$

3 The same observations remain constant for the earlier texts written in PhG (available from 1886 to 1960s) as well. Unfortunately I cannot exemplify all the permutations here, but see the contrast between the minimal pair in (i.a)-(i.b); $k i$ is present only in the former:

(i) a. Le ti ki, 'Amé son čarč́l' Say.IPFV.NPST.3SG DI KI go.IMP.2SG to.the.ACC bazaar.ACC 'He says, 'Go to the bazaar!' (Levidis 1892: 238.27)

b. Le ti, 'S pári to mutsúkon tu tin say.IPFV.NPST.3SG DI HORT take.PFV.NPST.3SG the little his the.ACC góri dáma če $s$ érti.'

daughter.ACC along and HORT come.PFV.NPST.3SG

'He says, 'Let him take his younger daughter along and let him come.' (Levidis 1892: $386.6)$

(For more examples, see Dawkins 1916: 466, 470, 472, 492, 496, 1955: 276, 277, 279; Theodoridis 1964: 290, 298, 306 a.o.). See also the following ones: In (ii.a) the subject of the reporting 


\section{(4) $\langle$ "Quote" $\rangle[$ Reporting Clause ... V(+cl) ... (XP) ... (ki) ... (XP)] “"Quote” $\rangle$}

As a first approximation, the speakers judge the quotative constructions with $k i$ to have a more emphatic tone than those in which no ki is present, which casts doubt on any assumption about its optionality.

\subsection{Predicate-complement constructions}

$K i$ can also optionally follow predicates selecting a complement clause provided that these are assertive predicates, such as léu ta kézi4 'presume', masáu 'vow', pandéxu 'suppose' (for assertive predicates, see Hooper and Thompson 1973; Hooper 1975). This is exemplified in (5a) with the non-factive assertive predicate, léu ta kézi 'presume'. Non-assertive predicates, such as strong factives, e.g., pušmanévu 'regret' or xárumi 'be glad', do not admit ki (5b) (for factive predicates, see Kiparsky and Kiparsky 1970; Karttunen 1971). Weak/semi-factive predicates, on the other hand, such as zrikáu 'realize', katéxu 'know', allow ki as long as their complement clause is not marked by the complementizer $t u$ (5c) (see especially Hooper and Thompson 1973: 48o-481 for how weak/semifactive predicates can in fact have a reading in which they are assertions, see also Bağriaçık in preparation for details in the $\mathrm{PhG}$ context). The complement clause following $k i$ can also be a semi-question (in the sense of Suñer 1993) (5d). Otherwise, predicates that select true indirect questions, such as rotáu 'ask', disallow $k i(5 \mathrm{e})$ :

clause, $i$ yrce 'the beldam', occurs between the verb and $k i$, and in (ii.b), the subject of the reporting clause, o vasilós 'the king', follows $k i$.

(ii) a. Ípen $i \quad$ zra $\quad$ ki, 'Aðefó su píge.' say.PFV.PST.3SG the.NOM beldam.NOM KI brother.NOM your leave.PFV.PST.3SG 'The beldam said, 'your brother left.' (Grégoire 1909: 159.9)

b. 'Na irti,' le di ki o vasilós [...] NA come.PFV.NPST.3SG say.IPFV.NPST.3SG DI KI the.NOM king.NOM “'He may come', says the king ...' (Grégoire 1909: 158.23)

These imply that (4) holds true for the earlier stages of PhG as well.

4 The predicate léu ta kézi 'presume' is a listeme (à la Di Sciullo and Williams 1987). kézi glossed here as 'presumably' (cf., Anastasiadis 1980: 120, $\chi \varepsilon^{\prime} \zeta(\lambda \alpha)$ '" $\left.\sigma \omega \varsigma^{\prime}\right)$, occurs only in this construction and it is not recognized in isolation by the speakers (at least today) (Iordanis Papadopoulos, pers. comm.). 
(5) a. Le ta kézi $\quad(k i)[a$ say.IPFV.NPST.3SG 3OBJ presumably KI FUT.DEF pikun to kači penendáu tun]. make.PFV.NPST.3PL the.ACC word.ACC among them 'He presumes that they are going to make an agreement among them.'

b. Pušmánepsin (da) $\left({ }^{*} k i\right)\left[\begin{array}{lll}\text { tu } & \text { co } & \text { xitsin }\end{array}\right.$ tarná regret.PFV.PST.3SG 3OBJ KI TU not run.PFV.PST.3SG fast so Xadzefendi]. to.the.ACC Haciefendi.ACC 'He regretted that she did not go to Haciefendi immediately'

c. zrikáu (ta) $\quad(k i)\left[\left({ }^{*} t u\right) a\right.$ $x a \theta i$ realize.IPFV.NPST.1SG 3OBJ KI TU FUT.DEF die.PFV.NPST.3SG son pónu tu]. from.the.ACC pain.ACC his 'I realize that he is going to die from his grief.'

d. Čú pin $m i$ (ta) (ki) [ cer na pírin not tell.PFV.PST.3PL 1SG.OBJ 3ОВJ KI if NA take.PFV.PST.3SG da paráda]. the.ACC money.ACC 'He didn't tell me whether he took the money.'
e. Rótsin
$m i$
(ta) $\left({ }^{*} k i\right)[$ tína
$a$
ask.PFV.PST.3SG 1SG.OBJ 3ОВJ KI who.ACC FUT.DEF 3OBJ ðósi tin góri tu].
give.PFV.NPST.3SG the.ACC daughter.ACC his
'He asked me to whom he is going to give his daughter.'

The only exception to the claim that the assertoric nature of the matrix predicate is a prerequisite for $k i$ to occur seems to come from a small subset of nonveridical predicates that select complement clauses headed by the particle $n a$ (generally known as subjunctive complements, on (non)-veridical predicates, see Giannakidou 1998, 2009): directive predicates (6a) or volitional predicates used as directives $(6 \mathrm{~b})$ allow $k i$ : 
(6)

a. Parakáltsin (da) (ki) [ (na) mu da fiči ]. beg.PFV.PST.3SG 3ОBJ KI NA not 3OBJ leave.PFV.NPST.3SG 'He begged her not to leave him.'

b. zrévi (ta) $o$ vasilós (ki) $[n a$ want.IPFV.NPST.3SG 3OBJ the.NOM king.NOM KI NA piésun čip tiz nomáti]. catch.PFV.NPST.3PL all the.ACC men.ACC 'The king wants (lit., orders) them to catch all the men.'

However, we will see in section 3.4 that at least structurally, these exceptional constructions and constructions with assertive predicates behave identically when there is ki following them (see especially fn. 21). With other non-veridical (hence non-assertive) predicates, such as modal verbs (7a), aspectual verbs $(7 \mathrm{~b})$ or typical volitional verbs $(7 \mathrm{c}) k i$ does not combine:
a. Čo pórka
(*i) [ na tavrísu
$t a$
not can.IPFV.PST.1SG KI NA pull.PFV.NPST.1SG the.ACC
tálce].
stones.ACC
'I could not haul the stones.'

b. Pitiésini

(*ki) [ na nási

ton

finish.PFV.PST.3SG KI NA plough.PFV.NPST.3SG the.ACC

tópu sos to vraði].

field.ACC until the evening

'He finished ploughing the field until the evening.'
c. Tanimazúxa irévi ( $\left.{ }^{*} k i\right)[n a$
early in the morning want.IPFV.NPST.3SG KI NA
fa suzzúta].
eat.PFV.NPST.3SG roasted.meat.ACC
'He wants to eat roasted meat, at the crack of dawn.'

Similar to the case in quotative constructions, matrix constituents can occur both between the matrix predicate and $k i$, and in post-ki position, as exemplified in (8) by the possibility of occurrence of the matrix subject-o nomát 'the man'-in both positions. This means that no strict-adjacency of ki with 
the verb or the complement clause is required. The word order facts are schematically presented in (9):5,6

5 Various instances of predicate-complement constructions with $k i$ are observed in the written texts as well:
. yo lézo
ti kézi
$k i \sin$
čufalén
palí
I.NOM Say.IPFV.NPST.ISG DI presumably KI to.the.ACC headship.ACC CONTR
a maryaósun.
FUT.DEF quarrel.PFV.NPST.3PL
'I presume (that) they will quarrel over the headship.' (Theodoridis 1966: 44.8)
b. yrévi vasilós ki en tu
understand.IPFV.NPST.3SG the.NOM king.NOM KI be.NPST.3SG that
¿ðe to fśaxókko.

see.PFV.PST.3SG the.NOM child.NOM

'The king realizes (that) he is the child that he saw.' (Levidis 1892: 383.36 )

All the tokens in these texts confirm the hypothesis that the assertoric nature of the matrix predicate is imperative for the occurence of $k i$ in predicate-complement constructions.

6 Note in passim that the generalization that the matrix predicate has to be assertive so that $k i$ can follow seems to hold generally true for quotative constructions as well (modulo the fact that in the latter construction the predicate in question is that of the reporting clause), yet there seems to be exceptions to this in the texts. One of them is the following where the predicate is rotáu 'ask':

(i) Rótse tin górin du ki, 'yo até to palikári ask.PFV.PST.3SG the.ACC daughter.ACC his KI I.NOM this the.ACC youth.ACC pítaksa da aðe na kópsete kelén du. send.PFV.PST.1SG 3OBJ here NA cut.PFV.NPST.2PL the.ACC head.ACC his Si a kóri mu sotípos to píjez atsé?' you.NOM INTERJ daughter.VOC my why 3OBJ do.PFV.PST.2SG such 'He asked his daughter, 'I sent this youth here, for you to cut off his head. Why, my daughter, have you done this?' (Dawkins 1916: 500.11)

Theodoros Theodoridis, who made corrections on the collection of stories in Dawkins (1916) in 1939 rewrites this sentence without $k i$ :
(ii) Róts
[...] tin
kórin
du [...] ' 'o té to
ask.PFV.PST.3SG
the.ACC daughter.ACC his
I.NOM this the.ACC
palikári pítaksa $t$ aðe na kópsete kellén
youth.ACC send.PFV.PST.1SG 3OBJ here NA cut.PFV.NPST.2PL the.ACC head.ACC 

(8) Ípin ta (o nomát) ki (o nomát) [cer say.PFV.PST.3SG 3ОВJ the.NOM man.NOM KI the.NOM man.NOM if na pírani ta paráda].
NA take.PFV.PST.3PL the.ACC money.ACC
'The man told us whether they took the money (or not).'

(9) $\left[\mathrm{CP} / \mathrm{TP}_{\text {matrix }} \mathrm{V}(+\mathrm{cl}) \ldots(\mathrm{XP}) \ldots(\mathbf{k i}) \ldots(\mathrm{XP})\left[\mathrm{CP}_{\text {embedded }} \ldots\right]\right]$

Similar to the case in quotative constructions, speakers universally judge predicate-complement constructions with $k i$ to be 'more emphatic' than their counterparts which do not involve $k i$.

\subsection{Causal constructions}

$K i$ is also employed in what will be referred to throughout as causal constructions. In such constructions, $k i$ seems to act as a special clausal 'coordinator' combining two finite clauses. It is special in that the overall meaning of the construction is limited to one where the first conjunct clause is taken to be the cause/justification of the proposition in the second conjunct clause. This construction contrasts with coordinate structures in which two finite clauses are coordinated with če (= Modern Greek, $k e$ ) 'and'. The relationship between the conjuncts in the latter can be temporal, sequential, causal, or even contrastive (see Ingria 2005: 70-72 for Modern Greek. The arguments presented there carry over to $\mathrm{PhG}$ as well.) Consider the following example:

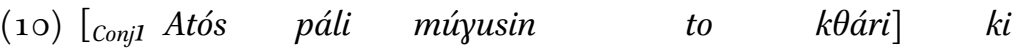
he.NOM CONTR hide.PFV.PST.3SG the.ACC barley.ACC KI
[conj2 Jókan da an katsára].
give.PFV.PST.3PL 3OBJ an admonition.NOM
'He hid the barley and (this is why) they scolded him.'
du. Si
a kóri
mu sotípos to pićez
aútsi?'
his you.NOM INTERJ daughter.voc my why 3ОBJ do.PFV.PST.2SG such
'He asked his daughter, 'I sent this youth here, for you to cut off his head. Why, my daughter, have you done this?' (Theodoridis 1939: A127)

\footnotetext{
It should be noted that these so-called corrections should be taken with caveat. At this point I am not sure if this deletion is due to a real correction or simply an omission. Moreover, occurrences of imperative quotes with $k i$, even when the predicate of the reporting clause is léu 'say' (for example, fn. 3, ex. (i.a)) constitue exceptions to the assumption that the predicate of the reporting clause has to be assertive so that ki can follow.
} 
According to the speaker, the reason why 'they scolded him', i.e., the subject of the construction, is expressed by the first clause, i.e., that 'he hid the barley'.

In these causal constructions, the first conjunct is not necessarily a direct justification of the eventuality expressed in the second conjunct. Consider the example in (11):
(11) $[$ Conjl $I$
Oíra ini
karakoménu] ki
the.NOM door.NOM be.NPST.3sg locked KI
[conj2 piini
so
šexéri o
Nikóas].

go.PFV.PST.3SG to.the.ACC city.ACC the.NOM Nick.NOM

'The door is locked and (this is why) Nick had gone to the city.'

In (11) above, the reason why Nick went to the city is not the fact that the door is locked. Rather, the speaker-who presumably had at her disposal the information that Nick might go to the city-infers, by observing that the door is locked, that Nick had indeed gone to the city. The first conjunct yields the reason for the speaker's belief that the proposition in the second conjunct is true, and it provides the justification for the argument in the second conjunct, not for the eventuality. As such, ki mediates a causal relation between the second conjunct and the speaker's epistemic attitude; the first conjunct clause providing the speaker's evidence for making the claim that Nick had gone to the city. In this sense, the first conjunct behaves as a type of peripheral adverbial clause ( pace Haegeman 2002, et seq., especially Haegeman 2012: 162), an argument-related causal clause (justifying clause) in particular, similar to the peripheral because clause:

(12) This is not a list drawn up by people sitting night after night reading to babies and toddlers, because then it would include books such as Boing! by Sean Taylor (Walker Books) which expand the child's experience along with his or her joy of reading. (Guardian, July 25, 2005: 9, col. 2, cited in Haegeman 2012: 162, ex. (28b))

Hence, I take the first conjunct in causal constructions to be an argumentrelated causal clause in Haegeman's sense, on a par with peripheral becauseclauses in English. ${ }^{7}$

7 See also the following construction from a written text where the first conjunct arguably receives the reading of an argument-related causal clause: 


\section{$2.4 \quad$ SE E-constructions}

It is not the case that in every construction where ki acts as a type of 'coordinator' the fist conjunct functions (only) as a justifying clause. Under certain circumstances, the verb of the first conjunct is superimposed a SEE-reading irrespective of its prototypical semantics or valency. In these constructions, which I refer to as SEE-constructions, according to the speaker, the subject of the first conjunct, in addition to the action that he carries out in the first conjunct, sees or realizes the eventuality in the second conjunct. Consider the example in $(13):^{8}$

(i) Tría xrónes častéftam tin pína če to three years be.tormented.PFV.PST.1PL with the.ACC hunger.ACC and the.ACC joxliéxi ki o teós son tušmáno mas na mi poverty.ACC KI the.NOM God.NOM to.the.ACC enemy.ACC our NA not ðiksi $t$ an to ta částe.

show.PFV.NPST.3SG 3OBJ like this the.ACC tortures

'For three years, we were tormented by hunger and poverty, so may God not show such tortures (even) to our enemy.' (Zurnatzis 1950s: 19.20)

8 Without extra linguistic clues, certain examples receive both SEE-reading and causal reading:

(i)

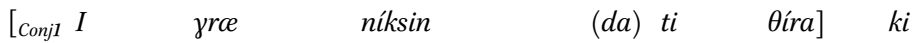

$$
\begin{aligned}
& \text { the.NOM beldam.NOM open.PFV.PST.3SG 3OBJ the.ACc door.ACC KI }
\end{aligned}
$$

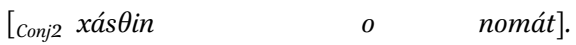

disappear.PFV.PST.3SG the.NOM man.NOM

reading 1: 'The beldam opened the door and so the man disappeared.'

reading 2: 'The beldam opened the door and (she saw that) man had disappeared.'

Such ambiguity is often resolved phonologically. In a causal construction reading, (i.e. reading 1) of the example (i), the first conjunct is strongly accentuated towards its right edge and no additional accentuation is present on $k i$. In the SE E-construction reading (i.e., reading 2) of the same example, on the other hand, the overall construction receives a somewhat flat intonation where $k i$ is slightly accentuated.

An anonymous reviewer suggested to me that the causal constructions and SEE-constructions may not be two distinct entities, but the SEE-meaning is the default interpretation as a matter of assertion and causal reading is the derived one. I agree with the reviewer on the fact that this may indeed be the case. This is also hinted at by the fact that I propose the same structural analysis for both construction types, according to which the first conjunct clause is an adverbial clause in both causal constructions and SEE-constructions (see section 3.3). The reason why I would still like to keep them in separate sections in the current paper is the ease of exposition. 


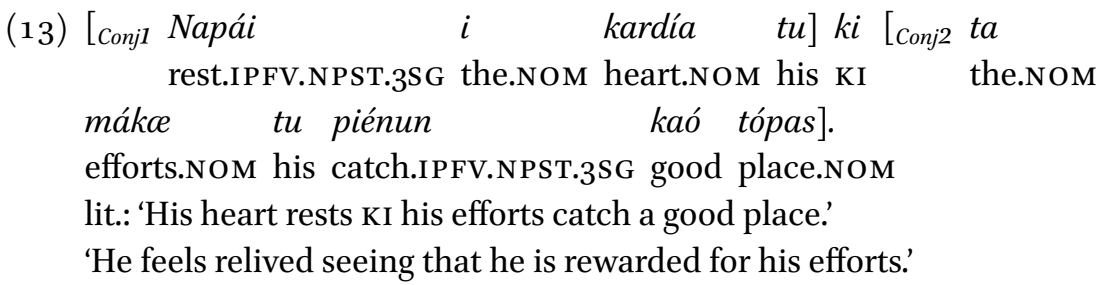

Beside its own semantics, the predicate in the first conjunct clause above is superimposed a SEE-reading, hence the example above can be paraphrased as follows: he feels relieved seeing that he is rewarded for his efforts. ${ }^{9}$

\subsection{Adverb + ki constructions}

Certain adverbs can be followed by the morpheme $k i$. These adverbs are exclusively copied from Turkish, such as pellé/paú 'obviously' ( $<\mathrm{T}$ (urkish), belli 'obvious'), temék 'apparently' (< T., demek 'that is to say' < de- 'to say'), matcem 'evidently' (< T., madem 'seeing (that)'), celpcetta 'certainly/surely' (< T., elbette 'certainly'), tabí 'definitely' (< T., tabii 'definitely/naturally'), and tamán 'undoubtedly' (< Turkish dialect of Central Anatolia, taman 'surely'). These adverbs are ambiguous between a speaker oriented (subjective modal) reading and a punctual/impersonal (objective modal) reading ((14a), (15a)) (for subjective and objective modal readings see Lyons 1977: 797-804, see also Bağrıçık in preparation for the details of the current proposal). However, when they are followed by $k i$, they receive an exclusively speaker oriented reading and lose their punctual/impersonal reading $((14 b),(15 b))$ :

9 See also the following example from Dawkins (1916):

(i)
Írten
to $\quad$ fśóko
sto
skólio $\quad k i$
come.PFV.PST.3SG the.NOM little.boy.NOM from.the.ACC school.ACC KI

énne si man du kondá o ghwríxos.
be.NPST.3sG in.the.ACC mother.ACC his near the.NOM lover.NOM
'The little boy came from the school; (he saw) that the lover had come to his mother.'
(Dawkins 1916: 474.15)

Noteworthy is the translation by Dawkins himself in which he added the phrase 'he saw' in parentheses. For more examples, see Dawkins (1916: 474.25, 504.11, 526.18). 
(14) a. Paú kečindánkani mo to kundelíki. obviously live on.IPFV.PST.3PL with the.ACC daily wage.ACC 'Obviously, they would make a living on daily wage.'/It is obvious that they would ...'

b. Paú ki kečindánkani mo to kundelíki. obviously KI live on.IPFV.PST.3PL with the.ACC daily wage.ACC 'Obviously, they would make a living on daily wage.'|"'It is obvious that they would ...'

(15) a. Álpcetta ató o nomát čo pírin ta certainly this the.NOM man.NOM not take.PFV.PST.3SG the.ACC paráða.

money.ACC

'Of course, this man did not take the money'//It is certain that this man ...'

b. Álpcetta ki ató o nomát čo pírin

certainly KI this the.NOM man.NOM not take.PFV.PST.3SG

ta paráda.

the.ACC money.ACC

'Of course, this man did not take the money.'/*'It is certain that this $\operatorname{man} . . . '$

The adverb $+k i$ sequence in $(14 \mathrm{~b})-(15 \mathrm{~b})$ cannot be interrupted by any lexi$\mathrm{cal} /$ functional material. This is exemplified in (16) below, where it is shown that the occurrence of the fronted constituent, ta paráda 'the money', between the adverb and the $k i$ is disallowed:

(16) Álpcetta ( ${ }^{*} t a \quad$ paráða) ki ató o nomát čo certainly the.ACC money.ACC KI this the.NOM man.NOM not pirin da.

take.PFV.PST.3SG 3ОВJ

int.: 'Of course, the money, this man did not take it.' (cf. (15b))

Not all types of adverbs admit ki following them. The co-occurrence of $k i$ with any lower adverb, such as adverbs modifying the verb phrase (e.g., tarná 'quickly') or aspectual adverbs (e.g., táima 'always') results in ungrammaticality $(17 \mathrm{a})-(17 \mathrm{~b})$ : 

(17) a. Tarná (*ki) xítsin so xoríu. quickly KI run.PFV.PST.3SG to.the.ACC village.ACC 'He went to the village quickly.'
b. Táima (*ki) éxu léiku čemémi so always KI have.NPST.1SG little fenugreek.ACC in.the.ACC spíti. house.ACC 'I always have a little fenugreek (paste) at home.'

On the other hand, it is also not any modal or speaker oriented adverb (cf. Jackendoff 1972; Alexiadou 1997; Cinque 1999) that admits ki. Evidential mood adverbs, for example, such as yojá 'allegedly' (18a) or mood irrealis adverbs such as xérxalta 'perhaps' (18b) cannot be followed by the morpheme ki:

Therefore ki can follow only a small set of modal adverbs which I identify here as epistemic adverbs (Speas 2004: 259, Ernst 2002). ${ }^{10}$

To recapitulate this section, only epistemic adverbs can co-occur with the $k i$ morpheme. The epistemic adverb in the adverb $+k i$ construction exclusively receives a speaker oriented reading. ${ }^{11}$

\footnotetext{
10 There seems, however, not to be a consensus on the exact status of such adverbials as evidently, clearly, obviously etc. Chafe (1986) and Palmer (1986) assign them into the class of evidential adverbs, whereas Ernst (2002: 73-75) and Speas (2004) treat them as epistemic adverbs. See also Cinque (1999: 174, fn. 37) who expressed his doubt about the status of this category and suggests that they "should perhaps be assigned to a distinct class". I will continue following Ernst (2002) and Speas (2004) in treating them as epistemic adverbs.

11 See also the following example from a written text:
} 


\subsection{Emphatic clauses}

$K i$ is also employed in the clause-final position. In such use, it is identified by the speakers as a particle lending emphatic force to the preceding clause. Such 'emphasis' is often executed as a contrast against a preceding presupposition. Consider the example in (19):

(19) A: - Why did you not sell anything when you came here to start a business? B: - Ači fikam čip tu ixami ki! there leave.PFV.PST.1PL all that have.PST.1PL KI 'We actually left everything we had there!'

In (19), B's response contrasts against a previous presupposition in A's question: A presupposes that в might have brought some (valuable) things with him/her into Greece during the population exchange, which could have helped him/her in starting a new business. With this presupposition in mind, A asks why в (or his family) did not sell these (valuable) things to raise capital. B's answer, however, contradicts the presupposition in A's question: they in fact had brought nothing with them to begin with. As such, $k i$ can, at first glance, be identified as the marker of counterpresupposition (adopting the term by Gussenhoven 2007) involving a correction of information which the speaker detects in the hearer's discourse model.

However, not all uses of clauses where $k i$ occurs in clause-final position can immediately be identified with counterpresupposition. Consider the example in (20):

(20) Piésin

aúča a vreši $\quad k i !$

catch.PFV.PST.3SG such a rain.NOM KI

'It started to rain so heavily, in fact!'

The sentence in (20) can be uttered without any presupposition entailed. Simply, the speaker who sees that there is a heavy shower outside can tell it to the addressee who has no knowledge of the rain in any way. In such a use, $k i$ simply reinforces the credibility of the speaker's proposition. Such uses of
(i)
ki gečindáme
mo to kundeliki.
obviously ki live.on.IPFV.NPST.1PL with the.ACC daily.wage.ACC
'Obviously, we live on daily wage.' (Theodoridis 1964: 322.2 )

Needless to say, it is not clear in such examples from the written texts whether the adverb retains its impersonal/punctual reading as well. 
$k i$ as in (20) suggest that it might not necessarily be directly related with (counter)presupposition-focus as the prima facie evidence in (19) indicates. Hence, I take ki's function as a contrastive particle to be secondarily derived from its primary function as amplifiying the reliability of the speaker's utterance. $^{12}$

For the sake of completeness, it should also be noted that some argument or adjunct constiuent of the clause can follow the $k i$ in emphatic clauses. These constituents, however, are outside the intonation pattern of the clause preceding $k i$ and there is an intonation break between $k i$ and these constituents. These suggest that these constituents are right-dislocated. This is exemplified in (21), where the direct object is right-dislocated:13
(21) Čo nápsa
ta ki, $t i$
nistía.
not light.PFV.PST.1SG зОВJ КI the.ACC fire.ACC
'I didn't light it, the fire!'

The previous six subsections presented a brief overview of all the possible $k i$ constructions in modern day PhG. The properties of these construction types are recapitulated in Table 1.

Table 1 shows that $k i$ seems to be a multifunctional morpheme occuring in a number of seemingly unrelated constructions. It occurs obligatorily in causaland SEE-constructions and somewhat optionally in the remaining construction types. It acts as a coordinator-albeit with a specific semantic contri-

12 A morphologically similar $k i$ occurs in a closely related variety, Pontic Greek, which is treated as a focus particle by Sitaridou and Kaltsa (2014). According to Drettas (2000: 128129), the Pontic Greek $k i$ is suffixed to the verb, whereas the clause-final $k i$ in PhG can lean onto words of any category. Therefore, I assume in this study that the $k i$ in Pontic Greek and the $k i$ in PhG should be kept apart. Note also that according to Drettas (2000), $k i$ in Pontic Greek is ultimately the Western Georgian particle $k^{\prime} i$, whereas I relate $k i$ in PhG with the Turkish $k i$.

13 Unfortunately, I could not retrieve any examples of purely emphatic clauses in the older written texts, but see for example, the construction in Papadopoulos (2011: 31.18). This may simply be a gap in recording. Anticipating later discussion, quotative constructions (and predicate-complement constructions) are structurally the same constructions as emphatic clauses. Therefore, I would like to cite the following example as an emphatic clause:
(i)
'Mo to Өeó, típos čo irévo!'
lézo
ti $k i !$
By God, nothing not want.IPFV.NPST.1SG say.IPFV.NPST.1SG DI KI
'By God! I want nothing!, I say!' (Theodoridis 1964: 298.33) 


\begin{tabular}{|c|c|c|}
\hline Construction type & Constituent order & Function of $k i$ \\
\hline Quotative-construction & $\begin{array}{l}\langle\text { “Quote" }\rangle[\text { Reporting Clause } \ldots . \mathrm{v}(+\mathrm{cl}) \ldots \\
(\mathrm{XP}) \ldots(\mathbf{k i}) \ldots(\mathrm{XP})]\langle\text { “Quote" }\rangle\end{array}$ & Emphasis \\
\hline $\begin{array}{l}\text { Predicate-complement } \\
\text { construction }\end{array}$ & $\begin{array}{l}{\left[\mathrm{CP} / \mathrm{TP}_{\text {matrix }} \mathrm{V}(+\mathrm{Cl}) \ldots(\mathrm{XP}) \ldots(\mathbf{k i}) \ldots\right.} \\
\left.(\mathrm{XP})\left[\mathrm{CP}_{\text {embedded }} \ldots\right]\right]\end{array}$ & Emphasis \\
\hline Causal-construction & {$[$ Clause $1 . .$.$] ki [$ Clause $2 . .]$.} & $\begin{array}{l}\text { Justification of } \\
\text { argument in Clause } 2\end{array}$ \\
\hline SEE-construction & {$[$ Clause $1 . ..] \mathbf{k i}[$ Clause $2 . .]$.} & $\begin{array}{l}\text { Superimposition of SEE } \\
\text { reading in Clause } 1\end{array}$ \\
\hline Adverb + ki construction & Adverb $_{\text {Epistemic }}+(\mathbf{k i}) \ldots$ & $\begin{array}{l}\text { Loss of impersonal / } \\
\text { punctual reading }\end{array}$ \\
\hline Emphatic clauses & {$\left[{ }_{\mathrm{CP} / \mathrm{TP}} \mathrm{V}+(\mathrm{cl}) \ldots(\mathrm{XP})(\mathbf{k i}) \ldots(\mathrm{XP})\right]$} & Emphasis \\
\hline
\end{tabular}

bution-, a clause-final emphatic particle, and an optional complementizerlike morpheme with specific semantic import. The question emerging from this picture is whether there are many homophonous kis, each with a specific function or the constructions presented above can be uniformly treated. In the next section, I will argue that there is in fact a unique functional $k i$ in $\mathrm{PhG}$ and these different construction types are results of different syntactic configurations involving this functional element.

\section{The analysis}

In this section, I will first present the theoretical framework adopted in the analysis of $k i$ (section 3.1) and identify $k i$ as a functional morpheme merged in the head position of Speech Act Phrase, providing evidence from adverb $+k i$ constructions (section 3.2). Finally the analysis will be extended to the remaining construction types in sections $3 \cdot 3-3 \cdot 4$.

\subsection{Theoretical framework}

The proposed analysis adopts the Cartographic Approach to the left periphery (cf. Rizzi 1997, 2004 and much subsequent work; especially Rizzi and Cinque 2016 for an up-to-date overview) which aims at providing fine-granied, universal hierarchies of functional projections, among which is the complementizer field, CP, such as the one proposed in Rizzi (2004: 242, ex. (6o)): 
(22) ForceP TopP* IntP TopP* FocusP ModP* TopP* FinP IP

Within such an approach and following the analysis offered for Modern Greek by Roussou (2000), Bağrıaçlk (in preparation) proposes the following (incomplete) functional hierarchy of the complementizer field in PhG:

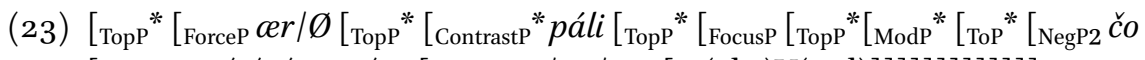
[СморP $n a / s / a /$ enna/xa $\left.\left.\left.\left.\left.\left.\left.\left.\left.\left.\left.\left.{ }_{\mathrm{NegP1}} \mathrm{mu} / \mathrm{mi} / \mathrm{ma}[\mathrm{IP}(\mathrm{cl}+) \mathrm{V}(+\mathrm{cl})]\right]\right]\right]\right]\right]\right]\right]\right]\right]\right]\right]\right]$

In a nutshell, clause-typing is encoded in ForceP which can be headed by the interrogative complementizer $e r$ and the null non-factive complementizer. The lower C-portion, CMODP encodes mood/ modality and is preceded and followed by distinct NegPs. ${ }^{14}$ Topic is recursive (recursivity shown by the asterisk, *) and is realized in various positions of the CP-layer whereas there is a unique Focus projection, the Spec of which hosts focused elements and $w$ h-operators. ContrastP is headed by páli and it hosts phrases which receive contrastive, nonexhaustive discourse reading (this is based on the analysis offered by Sitaridou and Kaltsa 2014 for $p a$ in Pontic Greek). Spec, ModP (Modifier Phrase and not Modal Phrase, cf. Rizzi 2004) hosts higher adverb(ials). Further partitioning of the ModP, following Giorgi (2010), into evaluative, evidential and epistemic projections is possible. The latter is in line with the original proposal of Cinque (1999) according to which functional head morphemes (affixes, clitics or auxiliaries) occur in a specific cross-linguistic order and that adverbs (or adverbials), which are not appendices to the clause structure but in fact intrinsic parts of it, are generated in specifier positions of such functional heads. In such a fixed relative order of adverbs and functional heads, Modal adverbs are expressed high in the clausal spine Cinque (1999: 84):

(24) $\operatorname{Mood}_{\text {speech act }} \mathrm{P}$ frankly $>\operatorname{Mood}_{\text {Evaluative }} \mathrm{P}$ fortunately $>\operatorname{Mood}_{\text {Evidential }} \mathrm{P}$ allegedly $>\operatorname{Mod}_{\text {Epistemic }} \mathrm{P}$ probably $>\mathrm{T}($ Past) once ... (Cinque, 1999: 106, ex. $(92))$

Unlike Cinque's original proposal, recent work locates such projections in the CP field above the IP (cf. Speas and Tenny 2003; Tenny 2006; Giorgi 2010; Haddican et al. 2014). Hence, identifying the ModP in (23) with the functional projections of $\operatorname{Mood}_{\text {Speech act }} \mathrm{P}, \operatorname{Mood}_{\text {Evaluative }} \mathrm{P}, \operatorname{Mood}_{\text {Evidential }} \mathrm{P}$ and $\operatorname{Mod}_{\text {Epistemic }} \mathrm{P}$ is - at least—conceptually supported (see Bağrıaçı in preparation for details).

$14 \mathrm{CMOD}^{0}$ hosts the subjunctive particle $n a$, the hortative particle $a$ and the future particles; $a$ 'definite future', énna 'indefinite future' and $x a$ 'future irrealis'. 


\subsection{The location of ki: evidence from adverb + ki constructions}

The piece of evidence for discovering the exact location of $k i$ in the clausal spine comes from adverb $+k i$ constructions: The occurrence of the epistemic adverbs below constituents occupying Spec, ContrastP is grammatical only when there is no $k i$ following these adverbs. The examples in (25) below are grammatical only when there is no ki following the adverbs tamán 'undoubtedly' and celpretta 'certainly' which follow the ContrastP (viz., páli, which occupies the Contrast $\left.^{0}\right)$ :

(25) a. Si páli tamán (*ki) a jásis. you.NOM CONTR undoubtedly KI FUT.DEF laugh.PFV.NPST.2SG 'Undoubtedly, you are going to laugh.'/'It is without doubt that you are going to laugh.'

b. Ta kuzukopéka mis páli aðé páli célpcetta (*ki) the.ACc morels.ACc we.NOM CONTR here CONTR certainly KI éxumi ta.

have.NPST.1PL 3OBJ

'Of course, the morels, we have them here.'/'it is certain that morels, we have them here.'

Therefore, the epistemic adverbs which occur in their base-position, i.e., Spec, ModP (precisely Spec, $\operatorname{Mod}_{\text {Epistemic }} P$ ), cannot be marked with ki. This suggests that ki does not occupy any head position below ContrastP. This is corroborated by the fact that the occurrence of $k i$ following an epistemic adverb becomes grammatical only when the epistemic adverb occupies a position above ContrastP:

(26) a. Tamán

(ki) si

páli a

jásis.

undoubtedly KI you.NOM CONTR FUT.DEF laugh.PFV.NPST.2SG 'Undoubtedly, you are going to laugh.'/'It is without doubt that ...' (cf. $(25 \mathrm{a}))$

b. Álpcetta (ki) ta kuzukopéka mis páli aðé páli certainly KI the.ACC morels.ACC we.NOM CONTR here CONTR éxumi ta.

have.NPST.1PL 3OBJ

'Of course, the morels, we have them here.'/It is certain that ...' (cf. $(25 \mathrm{~b}))$ 
In (26) the same adverbs as in (25) precede the constituents which occupy Spec, ContrastP and $k i$ is grammatical. Therefore, $k i$ should be located above ContrastP. ${ }^{15}$

The position that $k i$ occupies above ContrastP cannot be identified as a complementizer position, i.e., Force ${ }^{0}$ in (23), however, simply due to the fact that $k i$ is not a complementizer. The first piece of evidence for this is an indirect one. In a fairly large number of languages, certain modal adverb(ial)s (or adjectives) can be followed by a complementizer at the left-edge of the clause (Ramat and Ricca 1998: 212; Cinque 1999: 18-19), see for example the following example from Flemish dialects:

(27) Waarschijnlijk da Sofie Jella heeft gebeld. probably that $\mathrm{S}$. J. has called 'It is probably the case that Sofie has called Jella.' (Flemish dial., Aelbrecht 2006: 5, ex. (18b))

15 See also the fact that when the adverb is in any postverbal position, they cannot be followed by ki, as exemplified in (i.a)-(i.b) below:

(i) a. Ató o nomáts čo pírin ta paráða

this the.NOM man.NOM not take.PFV.PST.3SG the.ACC money.ACC temék ( $\left.{ }^{*} k i\right)$.

apparently $\mathrm{KI}$

'Apparently, this man did not take the money./'It is apparent that this man ...'

b. Ató o nomáts čo pírin temék (*ki) ta

this the.NOM man.NOM not take.PFV.PST.3SG apparently KI the.ACC paráða.

money.ACC

'Apparently, this man did not take the money.'/It is apparent that this man ...'

In (i.a) the adverb temék 'apparently' is in the clause-final position but the ki following the adverbs in this position is disallowed. Similarly, in (i.b), the same adverb occurs in immediately post-verbal(+clitic) position and again the occurrence of $k i$ following the adverb results in ungrammaticality. The ungramaticality of $k i$ in post-verbal position is explained as follows: The epistemic adverb is base generated in Spec, ModP (precisely in Spec, $\operatorname{Mod}_{\text {Epistemic }} \mathrm{P}$ ). The word orders in (i.a)-(i.b) are derived by Remnant movement (preceded by constituent topicalization) of at least the $\mathrm{Neg}_{2} \mathrm{P}$ (cf. Kayne 1994) to a topic position above the ModP. However, since ki does not occupy the head position of ModP (or any position in or below ContrastP), the occurrence of $k i$ in these positions is judged ungrammatical. 
One line of analysis (e.g., Aelbrecht 2006) argues that constructions such as the one in (27) are underlyingly bi-clausal, rather than mono-clausal, and they are obtained through the ellipsis/suppression of (phonologically) weak elements, such as the expletive, copula (and the adverb 'so' if any) (28):

(28) Het is waarschijnlijk zo da Sofie Jella heeft gebeld. It is probably so that $S$. J. has called 'It is probably the case that Sofie has called Jella.' (Flemish dial., Aelbrecht 2006: 5, ex. (18a))

Such a line of reasoning would face one major empirical problem if it were made for the PhG data: the adverbs which can be followed by ki admit neither the copula nor the adverb aúča 'so':

(29) a. * Íni paú aútsa ki kečindánkani mo
be.NPST.3SG obviously so KI live on.IPFV.PST.3PL with
to kundeliki.
the.ACC daily wage.ACC
int.: 'It is obviously so that they would live on daily wage.' (cf. (14b))
b. * Ini álpcetta aúča ki ató o nomát č
be.NPST.3SG certainly so KI this the.NOM man.NOM not
pírin ta paráða.
take.PFV.PST.3SG the.ACC money.ACC
int.: 'It is certainly so that this man did not take the money.' (cf. (15b))

The ungrammaticality of the co-occurrence of the copula and the adverb 'so' with the ki-admitting adverbs in (29a) and (29b) reveals that adverb $+k i$ constructions cannot derive from an underlying bi-clausal structure (i.e., with two VPs). This in turn suggests that $k i$ does not mediate a complementation relation between a matrix clause and a complement clause, a function typical of complementizers.

There are other pieces of evidence-albeit from predicate-complement constructions - in favor of the claim that $k i$ is not a complementizer. First, as shown previously in (8), constituents of the matrix clause in a predicatecomplement construction can occur in post- $k i$ position, which means that $k i$ does not form a maximal projection with the complement clause and therefore it cannot be a complementizer heading the complement clause. Second, complement clauses in $\mathrm{PhG}$ can be left dislocated, as exemplified in (30a). Crucially, the movement of ki along with the complement clause is not allowed ( $3 \mathrm{ob})$. On 
the other hand, if the complement clause is fronted without the ki morpheme, the structure is grammatical (3oc):

(30) a. [ Er na pírami ta paráda $]$ čo a
if NA take.PFV.PST.1PL the.ACC money.ACC not FUT.DEF
$d a \quad$ ipumi.
3OBJ tell.PFV.NPST.1PL
'Whether we took the money or not, we are not going to tell it.'
b. * [ Ki cer na pírami ta paráða] čo a
KI if NA take.PFV.PST.1PL the.ACC money.ACC not FUT.DEF da ipumi.
3OBJ tell.PFV.NPST.1PL

int: 'Whether we took the money or not, we are not going to tell it.'
c. [ Er na pírami ta paráða] čo $a \quad d a$ if NA take.PFV.PST.1PL the money not FUT.DEF 3 ОВJ ipumi $\quad k i$. tell.PFV.NPST.1PL KI

'Whether we took the money or not, we are not going to tell it.'

If $k i$ were to be taken as a complementizer, such fronting of the complement clause 'stranding' $k i$ behind (so to speak) would be ungrammatical, contrary to fact. Therefore, the idea that $k i$ is a complementizer cannot be maintained.

If this reasoning is on the right track, then we are forced to expand more the articulated CP structure in (23) to locate ki. In what follows, I will first show that there is in fact good semantic and empirical motivation for this expansion and later argue for the existence of a functional projection above ForceP where pragmatic roles are structurally represented (à la Speas and Tenny 2003).

As stated in section 2.5, there is an interpretational difference between epistemic adverbs which are followed by $k i$ and which are not, even though in both cases the adverbs have propositional scope: While adverbs without $k i$ can receive a punctual/impersonal reading, adverbs followed by $k i$ receive a purely speaker oriented reading. Recently Hill $(2007,2010,2012)$ showed that similar to the PhG case, in Romanian as well, adverbs in adverb + complementizer constructions receive only evidential/speaker-oriented interpretation (31a) whereas adverbs which are not followed by a complementizer can receive both a speaker oriented or a punctual reading $(31 b)$ : 
(31) a. Sigur că va veni.

Surely that will-3sg come

'Of course s/he's coming.'/*'It is certain that s/he's coming.'

b. Sigur va veni.

Surely will-3sg come

'Of course s/he's coming.'/It is certain that s/he's coming.'

To account for the semantic (and various structural) discrepancies between (31a) and (31b), Hill assigns them distinct structures. Based on Speas and Tenny's (2003) theory of Speech Act Phrases, she argues that pragmatic roles are encoded in a pragmatic field as a Speech Act Phrase (SAP) and when the adverb expresses only speaker-oriented reading (31a) it is merged in the head position of the SAP which includes the pragmatic features of sentience roles (especially speaker). SAP dominates ForceP, in the head position of which $c \breve{a}$ 'that' is merged. According to her analysis, then, (31a) is a mono-clausal construction, rather than a bi-clausal one. In (31b) on the other hand, the adverb is base-generated in the specifier position of the ModP, and the SAP can be activated covertly (See also Cruschina 2015 for an implementation of this analysis to Sicilian and Italian grammaticalized adverbs). This analysis is further elaborated on by Haegeman and Hill (2013) and Haegeman (2014) who, discussing certain discourse markers in Romanian and West Flemish, identify SAP projection further with the capacity of 'Epistemic Vigilance' (after Sperber et al. 2010; Wilson 2011), i.e., the capacity of the communicator to display her/his competence, benevolence and trustworthiness to the hearer (Wilson 2010: 16-18).

Along the lines of the analyses proposed by Hill (2007), Haegeman and Hill (2013) and Haegeman (2014), I propose that $k i$ is a discourse marker that is endowed with a [+sentience] feature indexing the speaker as the sentient individual whose point of view is reflected in a given sentence, and that is geared to influencing the epistemic vigilance mechanism of the hearer. The speaker resorts to this mechanism to express the strength of her belief in and commitment to the truth of her assertion. Given its semantic import in adverb $+k i$ constructions, and given the fact that it is not a complementizer, but is nevertheless rather high in the complementizer layer, I take it to be a functional morpheme merged in the head position of SAP, which immediately dominates ForceP. Hence, I expand the CP-structure given in (23) as follows: 


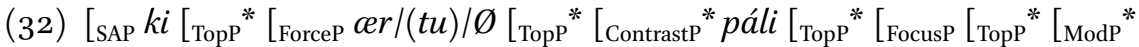
[ToP ${ }_{\text {TegP2 }} \check{c o}\left[{ }_{\mathrm{CmodP}} \mathrm{na} / \mathrm{s} / \mathrm{a} / \mathrm{enna} / \mathrm{xa}{ }_{\mathrm{NegP1}} \mathrm{mu} / \mathrm{mi} / \mathrm{ma}[\mathrm{IP}(\mathrm{cl}+) \mathrm{V}(+\mathrm{cl})\right.$ []]]]]]]]]]]]]

Diverging from the original proposal of Hill (2007) who argues that adverbs in adverb + complementizer sequence are merged in $\mathrm{SA}^{0}$ as heads, I propose that epistemic adverbs in adverb $+k i$ constructions are attracted to Spec, SAP, if SAP is projected, to check the [+sentience] feature on $k i$ (via spec-head configuration). One piece of evidence for the phrasal status of these adverbs comes from the fact that they can be modified (33a), precisely as they can when they are not in an adverb $+k i$ construction $(33 \mathrm{~b})$ :
a. $\check{C} a v$
tamán
ki o
nomát $a$
all the more undoubtedly KI the.NOM man.NOM FUT.DEF nárti.
come.PFV.NPST.3SG

'All the more undoubtedly, the man is coming.'

b. $\check{C} a v$

tamán

nomát $a$

all the more undoubtedly the.NOM man.NOM FUT.DEF

nárti.

come.PFV.NPST.3SG

'All the more undoubtedly, the man is coming.'/It is all the more without doubt ...'

The (partial) derivation of the adverb $+k i$ construction in $(14 \mathrm{~b})$, resumed below in $(34 a)$, is given in $(34 \mathrm{~b})$ :

(34) a. Pau

ki kečindánkani

mo to

kundeliki.

obviously KI live on.IPFV.PST.3PL with the.ACC daily wage.ACC

'Obviously, they would make a living on daily wage.'/*'It is obvious that they would ...'

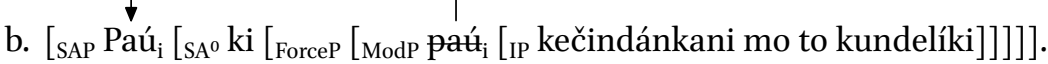

In the light of the analysis proposed here, the apparent optionality of $k i$ in cases such as those in (26), reduces to the fact that adverbs with or without a following $k i$ occupy distinct positions. Consider the minimal pair below in (35)-(36). In (35a), there is a ki following the epistemic adverb, and according to the analysis proposed above, the adverb is attracted to Spec, SAP, as in (35b). 
In (36a), where there is no $k i$, I propose that the adverb has moved from its base position, Spec, ModP, to a Topic position above the ContrastP, as shown in (36b). As has been argued by Rizzi (2004: 241), "[...] preposed adverbs can also be moved to a genuine topic position, with the familiar characteristics of ordinary topics [...]." Whether SAP may also be covertly activated in (36) when the speaker-oriented reading is obtained - as originally proposed by Hill (2007) for similar cases in Romanian—will be left open here:

(35) a. Tamán ki si páli a jásis. undoubtedly KI you.NOM CONTR FUT.DEF laugh.PFV.NPST.2SG 'Undoubtedly you are going to laugh.'

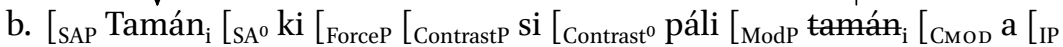
jásis]]]]]]]].

(36) a. Tamán si páli a jásis.

undoubtedly you.NOM CONTR FUT.DEF laugh.PFV.NPST.2SG

'Undoubtedly you are going to laugh.'/It is without doubt that you are going to laugh.'

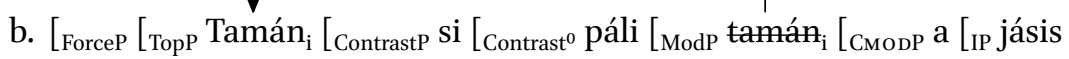
]]]]]]].

A final note is in order on the possibility of left dislocation to TopP: One of the sources of the relatively free order in PhG is the extensive use of movement to TopPs, which, adopting Rizzi's $(1997,2004)$ argument, are realized at multiple points in the CP, and above the CP, as Hanging Topic. I also assume that such a presumably Hanging Topic position is likely to occur above SAP:16

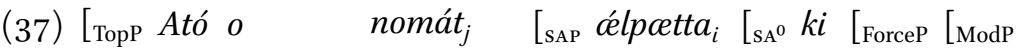 this the.NOM man.NOM certainly KI élpcetta ${ }_{i}\left[{ }_{\mathrm{NegP}} \check{c o}\right.$ [IP pírin $e_{j} t a \quad$ paráða]]]]]]]. not take.PFV.PST.3SG the.ACC money.ACC

'This man, of course, he did not take the money.'

16 Note that even if the topicalized constituent were to be assumed to move to this topic position, it is generally assumed that topic constituents head chains which do not interfere with adverb movement (Rizzi 2004). 
To conclude this section, $k i$ in adverb $+k i$ constructions has been identified as a device employed to influence interlocutor's epistemic vigilance. As such, it is argued to be the overt realization of $\mathrm{SA}^{0}$ which projects above ForceP. Why adverbs in adverb $+k i$ construction convey only speaker-oriented reading follows from the proposed configuration in which epistemic adverbs are attracted to Spec, SAP to check the sentience features. In the next two sections, the proposed analysis will be extended to the other-apparently unrelatedconstructions in which $k i$ is employed.

\subsection{SEE-constructions and causal constructions}

To anticipate later discussion in this section, I argue that in both SEE-constructions and causal constructions, the relationship between the two independent clauses, i.e., the first conjunct clause and the second conjunct clause, is mediated by the $\mathrm{SA}^{0}$, which is realized by $k i$. More specifically, the first conjunct in both construct types is base generated in the Spec, SAP of the second conjunct as adverbial clauses (for a similar base generation of reporting clause in interrogative slift constructions, see Haddican et al. 2014). This amounts to saying that (i) the two clauses in both construction types are not in a typical symmetric coordination relation, (ii) $k i$-similar to the case in adverb $+k i$ constructionsrealizes the $\mathrm{SA}^{0}$ in SEE- and causal constructions, and (iii) SAP which is headed by $k i$ is a functional projection of what we have been calling 'the second conjunct' (hereafter the second conjunct clause will be referred to as 'matrix clause' and the first conjunct clause will be referred as 'adverbial clause'). The structure of SEE-constructions (38a) and the structure of the causal constructions ( $38 \mathrm{~b})$ are both given in (39):
a. Napái $i$ kardía tu ki ta rest.IPFV.NPST.3SG the.NOM heart.NOM his KI the.NOM mákee tu piénun kaó tópas. efforts.NOM his catch.IPFV.NPST.3SG good place.NOM 'He feels relived seeing that he is rewarded for his efforts.'

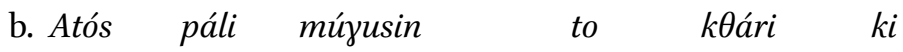
he.NOM CONTR hide.PFV.PST.3SG the.ACC barley.ACC KI Jókan da an katsára. give.PFV.PST.3PL 3OBJ an admonition.NOM 'He hid the barley and (this is why) they scolded him.' 


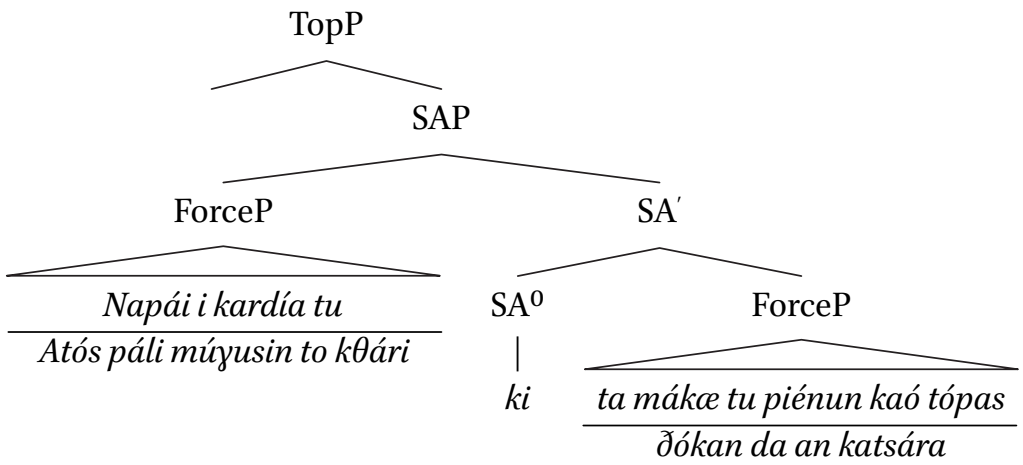

Let us now consider each construction type in detail.

First, consider the SEE-construction: the fact that any verb may obtain SEEreading in the first conjunct of a SEE-construction regardless of its own semantics and valency can be partly explained by the structure in (39) following Rooryck's account (2001) for quotative constructions.

Rooryck (2001) observes that virtually any verb of bodily-movement in the reporting clause of a quotative construction can receive a SAY-reading; for instance, the verb tremble below in (40) is assosicated with a SAY-meaning:

(40) 'Jules is back', trembled Jan. (Rooryck, 2001: 132, ex. (37a))

He argues that such a sAY-reading superimposed on any verb of bodily movement in a quotative construction can be explained once we accept that the relationship between the quote and the reporting clause is mediated by $\operatorname{Mood}_{\text {Evidential }}{ }^{0}$ (see also Haddican et al. 2014) and once we assume-following Cinque (1999) - that the default interpretation of $\operatorname{Mood}_{\text {Evidential }} \mathrm{P}$ involves a SAYmeaning: Within such an account, the verb of the reporting clause moves to $\operatorname{Mood}_{\text {Evidential }}{ }^{0}$ ( pace Rooryck 2001). Verbs without inherent evidential meaning, such as verbs of bodily movement, then, are 'adverbialized' via this movement and due to the lack of semantic 'matching' between the evidential restriction in $\operatorname{Mood}_{\text {Evidential }}{ }^{0}$ and the verb of bodily movement, which is without inherent evidential meaning, the 'default' SAY-meaning on $\operatorname{Mood}_{\text {Evidential }}{ }^{0}$ is triggered, while these verbs retain their own semantics as well. Hence, the syntactic process of verb movement to an 'adverbial head' (Rooryck 2001: 132) of the example in (40) derives the meaning in (41):

(41) The information content 'Jules is back' is stated by Jan by/while trembling. (Rooryck, 2001: 132, ex. (37b)) 
I propose that a similar line of reasoning as the one put forward by Rooryck for quotative constructions can be evoked for the SEE-constructions. Let us remember that SAP is the functional projection where 'epistemic vigilance', the capacity of the communicator to display her/his competence, benevolence and trustworthiness to the hearer is encoded. Epistemic vigilance mechanisms may be to display openly the degree of confidence about the truth of the speaker's assertion or the type of evidence the speaker has, and as stated by Speas (2004: 264), "personal experience and direct perception are the most reliable types of evidence". Once vision is accepted as a type of reliable evidence-and by common wisdom, it should be ${ }^{17}$-, then we can assume that SAP may involve a default SEE-meaning, just as $\operatorname{Mood}_{\text {Evidential }} \mathrm{P}^{\prime} \mathrm{s}$ default SAY-meaning. At first glance, this may seem imaginative but there is at least one case which can backup this idea. According to the account provided by Gordon (1986), in Maricopa, a Yuman-Cochimí language, there is a certain suffix grammaticalized out of the verb see:

(42) ${ }^{2}-i i m a-k ' y u u$

1s-dance-k=SEE $=\mathrm{EV}$

'I danced (for sure in the past)' (Maricopa:Yuman-Cochimí; Gordon 1986: 77 , ex. (6))

According to Gordon, the suffix $-k^{2} y u u$ in (42) is a 'sight evidential' and '[...] is used when the speaker is sure of the facts. Things which are sensed, though not seen, are as real as those which are directly seen' (Gordon 1986: 77-78). The suffix is an epistemic vigilance mechanism employed by the speaker to display her/his high degree of confidence about the truth of the her assertion. Hence, the suffix is in a way the counterpart of $k i$ in Maricopa and can be related to SAP.

In PhG, then, the fact that virtually any verb in the adverbial clause can be superimposed a SEE-meaning in SEE-constructions is due to the fact that such adverbial clauses are merged in Spec, SAP, and hence in a spec-head configuration with $k i$. The verb retains its own semantics and valency, nevertheless the $\mathrm{SEE}$-meaning on $\mathrm{SA}^{0}$ is triggered. This is the reason I propose for why $(38 \mathrm{a})$ can be paraphrased as follows: 'he feels relived seeing that he is rewarded for his efforts'.

17 Beyond common wisdom, Russell (1954 [1927]: 165-168, ch. XVI) argues that sight, as a source of knowledge and evidence concerning the world, is markedly the best of senses. I am grateful to an anonymous reviewer for bringing this reference to my attention. Willett (1988: 57) also argues that one type of direct (i.e., attested) evidence is the one which is obtained visually. 
Next, consider the causal constructions. In examples such as $(38 b)$, the adverbial clause base generated in Spec, SAP conveys the justification for the speaker's belief that the proposition in the matrix clause is true. As stated in section 2.3, the adverbial clause provides the justification for the argument in the matrix clause, not for the eventuality per se. As such, there is an epistemic linkage between the adverbial clause and the matrix clause. This relation, I propose, is encoded at the speech act level, i.e., via SAP. The speaker wants the hearer to believe the proposition in the matrix clause. In the lack of additional information (about the source or type of the knowledge), however, she is not sure whether the proposition will be conveyed properly to the hearer. Then an obvious way to get past the epistemic vigilance mechanisms of the listener is to display him openly the type of evidence she has (Sperber et al. 2010; Wilson 2011) for the argument/proposition. In a causal construction then, the adverbial clause provides the evidence for the truth of the proposition expressed in the matrix clause.

Beside providing us with some explanation for the particular (and sometimes overlapping) semantics of the two constructions involving $k i$, the structure I propose in (39) also enables us to account for certain structural idiosyncrasies of these constructions. In (39), both the matrix clause and the adverbial clause are taken to be main (i.e., root) clauses and hence they are expected to exhibit main clause phenomena (for main clause phenomena, see, among others, Haegeman 2012 and the references therein). This is verified in (43a)(43b) respectively, where the matrix clause and the adverbial clause are headed by the modal (hortative) particle $s$ (see Roussou and Tsangalidis 2010: $5^{2}$ who argue for Modern Greek that the particle as ( $=s$ in PhG) is confined to main clauses. The argument carries over to $\mathrm{PhG}$ as well, Bağriaçlk in preparation):

$$
\begin{aligned}
& \text { a. }\left[{ } _ { s A P } \text { Častéfta polí mo to joxliéxi } \left[{ }_{s A^{o}} k i\right.\right. \\
& \text { suffer.PFV.PST.1SG a.lot with the.ACC poverty.ACC KI } \\
& \text { [Forcep } s \text { da fikum xáre]]]. } \\
& \text { HORT 3OBJ leave.PFV.NPST.1PL now }
\end{aligned}
$$

'I suffered a lot from poverty (so) let's leave it, i.e., let's not talk about it now.'

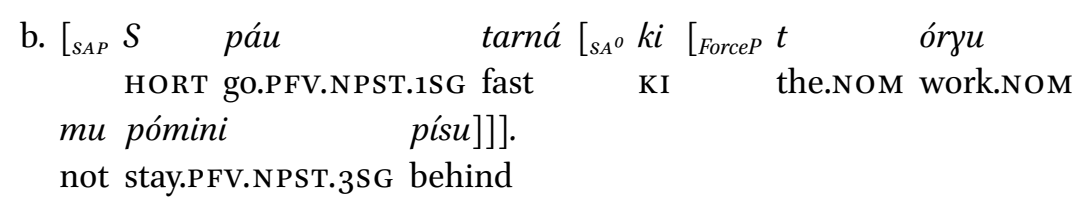

'Let me go fast so that the work is not delayed.' 
Next, let us return to the extraction facts. In (44), it is shown that whmovement from within the second conjunct - which I now argue is the matrix clause-is ungrammatical, as there is no Focus position above SAP which could attract the $w h$-constituent (both referential and non-referential wh-operators are equally ungrammatical):
(44) * Túnus so pšáka ${ }_{i}$ [saP atós páli whose to.the.ACC brother.ACC he.NOM CONTR múfusin to kөári $\left[{ }_{{ }^{\circ}{ }^{\circ}} k i\right.$ hide.PFV.PST.3SG the.ACc barley.ACC KI [Forcep Jókan da an katsára $t_{i}$ so give.PFV.PST.3PL 3OBJ an admonition.NOM in.the.ACC xoríu pésu]]]?
village.ACc inside
int.: 'Whose brother did they scold in the village because he hid the barley?'

Note that $w$-movement to Spec, FocP within the matrix clause is otherwise grammatical (45): 18

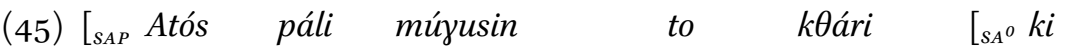 he.NOM CONTR hide.PFV.PST.3SG the.ACc barley.ACC KI [ForceP $_{\text {FocP }}$ pos $_{i}{ }_{\text {IP }}$ ta Jókan $t_{i}$ so xoríu what $3 \mathrm{OBJ}$ give.PFV.PST.3PL in.the.ACC village.ACC pésu]]]]]?
inside

'He hid the barley and so what did they give him?'

As expected from the structure in (39), a negative polarity item (e.g., típus 'nothing' below) within the matrix clause cannot be licensed by the negation in the adverbial clause due to the lack of c-command:

18 As the adverbial clause has its own illocutionary force, it can also be a question:

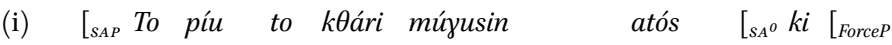
the which the barley hide.PFV.PST.3SG he.NOM KI Jókan da an katsára so xoríu pésu]]]? give.PFV.PST.3PL 3 ОВJ an admonition.NOM in.the.ACC village.ACC inside 'Which barley did he hide (so that) they scolded him in the village?' 

(46) * Čo síkosin to čúli ki típus
not lift.PFV.PST.3SG the.ACC rug.ACC KI nothing
pómini sa paráða.

remain.PFV.PST.3SG from.the.ACC money.ACC

int.: 'He didn't lift the rug and (saw that) nothing was left from the money.'

The structure in (39) then neatly explains the ungrammaticality in (44) and (46), without resorting to an explanation based on the-somehow problematic-Coordinate Structure Constraint Ross (1967:98-99). Rather than evoking this constraint as a primitive, we can now account for the ungrammaticality of (44) with the fact that there is no focus position above the SAP that would otherwise attract the $w h$-operator, and the ungrammaticality in (46) with the fact that the negator in the adverbial clause is not in the proper configuration to license the NPI in the matrix clause. ${ }^{19}$

For the sake of completeness, it should be noted that, similar to the case in adverb $+k i$ constructions, a topic position above the SAP where probably hanging topics are hosted, is predicted to occur in SEE- and causal constructions as well. This prediction is borne out. In (47), it is shown that the constituent, azóri katsára 'a good admonition', linked to a position in the matrix clause, is hosted in this position:

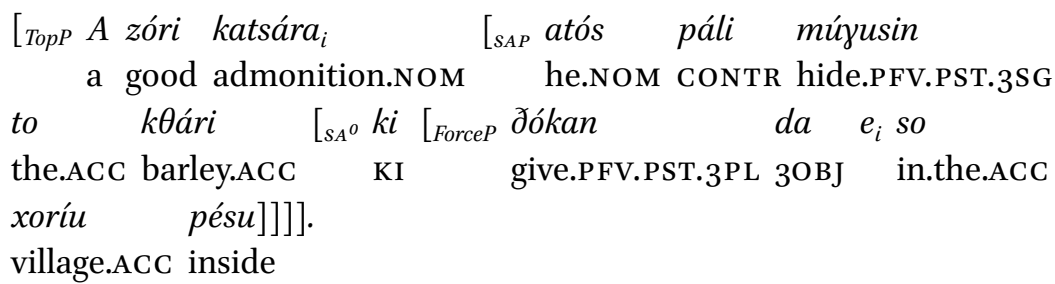

'A good admonition, he hid the barley and (this is why) they gave him in the village.'

To sum up this section, identifying the first conjuncts both in SEE-constructions and causal constructions as adverbial clauses merged in Spec, SAP accounts both for the semantic relationship holding between these adverbial clauses and the matrix clauses they modify, and for the structural peculiarities of

\footnotetext{
19 Similar ungrammatical results are obtained from relativization, which, due to space limitations, I cannot provide here. No constituent from the adverbial or the matrix clause can be relativized, as expected. See Bağrıaçık (in preparation) for details.
} 
these constructions, which at first glance resemble coordinate structures. ${ }^{20}$ In the next section, I will return to the quotative constructions, predicatecomplement constructions and the emphatic clauses and argue that they can be treated uniformly, once again invoking the analysis based on SAP.

\subsection{Predicate-complement and quotative constructions, and emphatic clauses}

It is noteworthy that only assertive predicates can be followed by ki (section 2.2). Assertions are typically associated with the speaker Hooper and Thompson (1973). Next, consider also the fact that whenever ki follows an assertive predicate taking a complement clause, it comes with a certain semantic contribution. The speakers universally judge the matrix predicate in (48b), which is followed by $k i$, as being 'more emphatic', or as being 'stronger in conveying the assertion' than its counterpart in (48a):
(48) a. zrikáu
(ta) $a$
xaAó.
see.IPFV.NPST.1SG 3OBJ FUT.DEF die.PFV.NPST.1SG
'I realize that I am going to die.'
b. yrikáu ta ki a xaAó.
see.IPFV.NPST.1SG 3ОBJ KI FUT.DEF die.PFV.NPST.1SG
'I realize that I am going to die.'

The example in (48b) is discourse-wise salient only when the speaker strongly believes that this is the case, e.g., when she is on the verge of death. The example (48a) on the other hand, does not carry such extra information; modal-wise it is neutral. The speaker is making a neutral statement that she is going to die, without showing a strong commitment to the assertion. The fact that there is a strong speaker commitment to the truth of the propositions in complement clauses following $k i$ means that these propositions cannot be easily contradicted by the same speaker or these sentences cannot be uttered figuratively (see Bağriaçık in preparation for details).

Such speaker judgments can be neatly captured if we continue to treat $k i$ as a discourse marker with which the speaker shows her commitment to

20 A subsidiary advantage of the analysis proposed above is that it may also account for the ambiguity between SEE-constructions and causal constructions in the absence of extra linguistic clues (see $\mathrm{fn}(8)$ ). If both types of adverbial clauses are base-generated in Spec, $\mathrm{SAP}$, in the absence of further linguistic clues for its resolution, such ambiguity does not come as a surprise. 
the truth of her assertion. Relating $k i$ with such function may also capture a few interesting structural differences between predicate-complement constructions with and without $k i$. These differences will also enable us to propose a unified account of the quotative constructions and emphatic clauses. Let us assume that $k i$ in predicate-complement constructions - similar to adverb $+k i$ constructions, causal constructions and SEE-constructions-is the overt realization of $\mathrm{SA}^{0}$. In the absence of any epistemic modal constituent, for example an adverb, which could be attracted to Spec, SAP, the matrix clause including the matrix verb (ForceP) is attracted to the same position, for checking the sentience features on $k i$. A result of this movement is the fact that a modifying adverb $+k i$ sequence is ungrammatical with a predicate-complement construction with $k i$ due to the non-recursive character of SAP, even though the adverb is semantically compatible with the attitude of the speaker:
( $\left.{ }^{*} P a u ́ \quad k i\right)$ yrévi
ta ki xitsin
tarná
obviously KI see.IPFV.NPST.3SG 3ОВJ KI run.PFV.PST.3SG fast
so Xadzefendí.
to.the.Acc Haciefendi.Acc
'(*Obviously) he sees that she went to Haciefendi immediately.'

At first glance such movement of the matrix ForceP seems not to get the word order facts right since the complement clause would then be pied-piped by the matrix clause yielding the following structure:

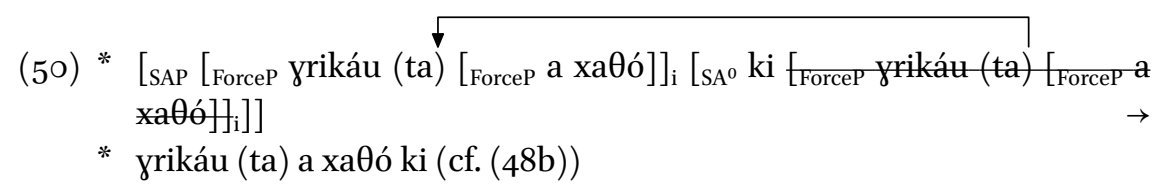

However, there are certain structural differences between predicate-complement constructions with and without $k i$, which provide evidence for a movement analysis; for instance, in the environment of ki, extraction from the complement clause to the matrix clause becomes unavailable. Consider the minimal pair in (51):
(51) a. Pos $_{i}$ pandéxis
(ta) [ Jóčin
$o$
what think.IPFV.NPST.2SG 3OBJ give.PFV.PST.3SG the.NOM
nomát $t_{i}$ so Xadzefendi]?
man.NOM to.the.ACC Haciefendi.ACC
'What do you think the man gave to Haciefendi?' 
b. ${ }^{*} \mathrm{Pos}_{i}$ pandéxis ta ki [ Jóčin o what think.IPFV.NPST.2SG 3OBJ KI give.PFV.PST.3SG the.NOM nomát $t_{i}$ so Xadzefendi]?

man.NOM to.the.ACC Haciefendi.ACC int.: 'What do you think the man gave to Haciefendi?'

Wh-movement from within the complement clause to the left periphery of the matrix clause is blocked by $k i$, as the difference between (51a) and (51b) shows. Another difference is the fact that an NPI in the complement clause cannot be licenced by the negation in the matrix clause in predicate-complement constructions if $k i$ is present: ${ }^{21}$

(52) a. Čo pandéxu (ta) típus pómini.

not think.IPFV.NPST.1SG 3ОВJ nothing remain.PFV.PST.3SG

'I don't think that anything remained, i.e., is left.'

b. * Čo pandéxu ta ki típus pómini.

not think.IPFV.NPST.1SG 3OBJ KI nothing remain.PFV.PST.3SG

int.: 'I don't think that anything remained, i.e., is left.'

21 The fact that ki blocks extraction and NPI licensing is also observed when the matrix predicate is one which selects a $n a$-clause (i.e., a subjunctive clause) (i.e., a directive predicate or a volitional predicate employed as a directive, see (6) and the discussion around it):

(i) * Tína ${ }_{i}$ grévi ta vasilós ki [ $\mathrm{na}$

who.ACC want.IPFV.NPST.3SG 3 OBJ the.NOM king.NOM KI NA

piésun $i$ askéri $t_{i}$ ?

catch.PFV.NPST.3PL the.NOM soldiers.NOM

int.: 'Whom does the king want (lit., order) the soldiers to catch?'

(ii) * Čo parakáltsin da ki típus na fámi.

not beg.PFV.PST.3SG 3OBJ KI nothing NA eat.PFV.NPST.1PL

int.: 'He didn't beg us to eat anything.'

The sentence in (i) becomes grammatical only when $k i$ is removed (tína irévi ( $t a)$ o vasilós na piésun i askéri?), and the sentence in (ii) becomes grammatical if $k i$ is removed or if the modal negator $m i / m u$, which licenses the NPI, is present in the complement clause: parakáltsin da ki típus na mu fámi. 
Hence, following the analysis by Bennis (1987) and Grange and Haegeman (1989) for extraposed clauses in Dutch and West Flemish, I assume that the complement clauses in the environment of $k i$ should be taken not as genuine complement clauses but as adjuncts. In effect, then, in the absence of any overt epistemic material, say, an adverb, it is the matrix ForceP (without the apparent complement clause) which moves to Spec, SAP to check the sentience features on $k i$ (by being in a spec-head configuration with $k i$ ). The apparent complement clause is linked to this moved ForceP via adjunction, as shown in (53) below: $:^{22,23}$

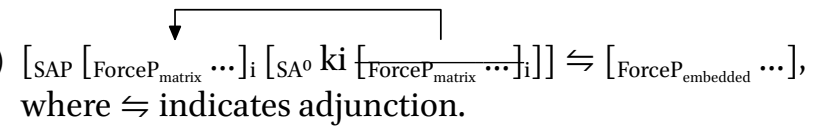

According to (53), the derivation of the predicate-complement construction in $(48 b)$ is as in (54):

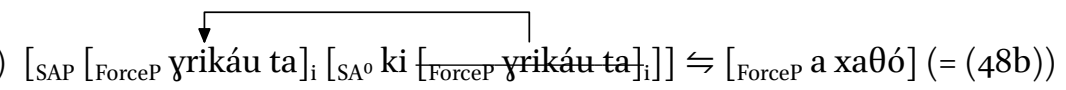

Interestingly, this analysis makes it possible to treat quotative constructions on par with predicate-complement constructions by assuming the same movement operation of the reporting clause (ForceP) to Spec, SAP. This amounts to saying that quotations in quotative constructions and apparent complement clauses in predicate-complement clauses involving $k i$ are of similar status. The derivation of (3a), resumed below as $(55)$, is given in $\left(5^{6}\right):^{24}$

22 The exact nature of these 'adjunct-complement clauses' will be left as an open issue in this study. In a strictly antisymmetric framework (e.g., Kayne 1994), which allows only one adjunction to a maximal projection, which can be identified with the unique specifier, this adjunction analysis remains inadequate. See, however, Bağrıaçı (in preparation) for a solution.

23 The clitic doubling facts only partly verify this claim. The third person clitic, $t a / d a$ is in fact obligatory in the predicate-complement constructions involving $k i$, therefore, we could assume that the matrix verb's theta-role that is to be assigned to the complement clause is instead assigned to the clitic. However, the clitic ta/da is also irregularly employed as a quasi-obligatory object marker with complement clauses without $k i$ and with DP arguments—even with non-referential ones (see also Dawkins 1916: 172 and Janse 1998: $538-540$ for earlier observations). The unsystematic nature of this clitic doubling might be due to 'grammar competition' (Kroch 1989), which in most cases results in a (diachronically) unstable situation, yet I leave the assessment of the hypothesis to future work.

Similar to the case of the complement clause in predicate-complement constructions, the 
(55) Le ta o tatás tu ki, Naátara

say.IPFV.NPST.3SG 3OBJ the.NOM father.NOM his KI how much

irévis na mi ta ðos?'

want.2SG NA 1SG.OBJ 3OBJ give.PFV.NPST.2SG

'His father says, 'How much [money] do you want to sell it to me?' (= (3a))

(56) $\left[\mathrm{SAP}\left[\text { ForceP }_{\text {Le ta o tatás } \mathrm{tu}}\right]_{\mathrm{i}}\left[\mathrm{SA}^{0} \mathrm{ki}\left[{ }_{\text {ForceP }} \text { le ta o tatás tu }\right]_{\mathrm{i}}\right]\right] \leftrightharpoons$ 'Naátara irévis na mi ta ðos?'

According to the analysis proposed here, the difference between quotative constructions/predicate-complement constructions on the one hand and the emphatic clauses on the other hand reduces to the fact that only in the former is there a constituent (an ostensible complement clause or a quote) which is linked to the matrix verb in one way or the other. In emphatic clauses as well, it is simply the (matrix) ForceP which is attracted to Spec, SAP and it is this very movement that makes the construction to be judged 'emphatic' on a par with quotative constructions and predicate-complement constructions with $k i$. The derivation of (57), reproduced from (20), is given in $\left(5^{8}\right):{ }^{25}$

\section{Piésin \\ aúča a vreši ki! \\ catch.PFV.PST.3SG such a rain.NOM KI}

'It started to rain so heavily, in fact!' $(=(20))$

(58) [SAP [ForceP Piésin aúča a vreší $\left.\left.]_{\mathrm{i}}\left[\mathrm{SA}^{0} \text { ki [ForceP piésin aúča a vreší }\right]_{\mathrm{i}}\right]\right]$

One piece of evidence in favor of this unified analysis of the three construction types is the fact that predicate-complement constructions and emphatic clauses are in complementary distribution: A predicate-complement construction cannot act further as an emphatic clause (see (59)). In structural terms this means that the matrix ForceP cannot move to Spec, SAP, dragging along the complement ForceP, so to speak (6o):

exact nature of adjunction, i.e., linking, of the quote to the reporting clause will be left open (see fn. 22). For various proposals see Collins and Branigan (1997); Suñer (200o); de Vries (2006).

25 Matrix constituents (shown as XPs in Table 1) which occur following $k i$ in all the three types of constructions analyzed in this section can then be treated as constituents which move to a topic position above ForceP before the ForceP remnant-moves to Spec, SAP. This is also in line with the assumption that these constitents are dislocated. See the examples (3b), (8) and (21), and the discussion revolving around the latter. 
(59) * zrikáu ta a xaقó ki!

see.IPFV.NPST.1SG 3OBJ FUT.DEF die.PFV.NPST.1SG KI

int.: 'I realize that I am going to die, in fact!'

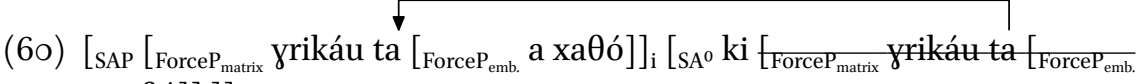
axaló][i]]

As shown in (53)-(54) above, the complement clause in the environment of $k i$ is always an apparent one which is not linked to the matrix clause by conventional means of complementation, and due to this reason it can never move along the matrix clause, as the ungrammaticality in (59)-(6o) verifies. ${ }^{26}$

To conclude this section, I have proposed that the structural differences between quotative constructions, predicate-complement constructions and emphatic clauses with $k i$ reduce to the existence of a constituent (a quote or an apparent complement clause) which is linked to the matrix verb in one way or the other. In each construction type, the matrix ForceP is attracted to Spec, sAP by virtue of which the speaker displays her commitment to the truth of her assertion.

\section{4}

\section{Conclusions and avenues for further research}

The current paper proposed a unified account for the ki particle in the modern Greek dialect of Pharasa, which is employed in a number of seemingly unrelated constructions. Under close scrutiny, it has been revealed that in each type of these apparently unrelated constructions, $k i$ is a device to which the speaker resorts in order to display the strength of her belief in and commitment to the truth of her assertion. Within the cartographic approach to the left periphery of clauses, $k i$ has been identified as a morpheme endowed with a

26 There is one potential problem with this 'movement of the (matrix) ForceP' analysis: it violates the anti-locality constraint, i.e., constraint on the movement of a complement to the specifier of the same projection, cf. Abels (2003); Grohmann (2003). I have no good solution for this, yet, if we take seriously the original idea by Speas and Tenny (2003), who argue that the interfacing between syntax and conversational pragmatics is established through a functional predicative structure in the same way that the argument structure of a lexical verb is projected, and that the speech act is computed in the same way as the functional 'little $v$ ', then we may even argue for the existence of 'little $s a^{\prime}$ ' i.e., $s a$ P above SAP. It might be the case that the ForceP is attacted to Spec, $s a \mathrm{P}$, modulo $\mathrm{sA}^{0}-s a^{0}$ head movement of $k i$, hence the anti-locality constraint is respected. 
[+ sentience] feature indexing the speaker as the sentient mind and merged in the head position of Speech Act Phrase (SAP) above ForceP. The apparent surface differences between various construction types involving $k i$ are claimed to follow from whether the [+sentience] feature on $k i$ is checked by an internally or externally merging category in Spec, SAP. The analysis proposed in the current paper not only offers an explanation for semantic and structural similarities between various construction types but it also clarifies why $k i$ resembles a complementizer, a clause-final emphatic particle or a coordinator in certain cases, even though it is in fact none.

Though interesting, the current paper has not addressed a number of issues pertinent to the origin of $k i$ and how $k i$ is accommodated into PhG clause structure. One of these issues is how $k i$ was borrowed from Turkish in the first place, and whether there is variation between the donor and the recipient languages with respect to the function of $k i$-elements. To note rather briefly here, $k i$ in Turkish has traditionally been assumed to introduce finite subordinate clauses of the Indo-European style (61a) (Erguvanlı 1980-1981; Johanson 1996; Kornfilt 1997), whereas native subordinate clauses are reduced in TAM and bear nominalization markers (61b):
a. İst-iyor-um ${ }_{{ }_{C P}} k i$ yarı ben-im-le sinema-ya want-PROG-1SG that tomorrow I-GEN.1SG-COM cinema-DAT gel-esin]. come-OPT.2SG 'I want you to come to the movies with me tomorrow.' lit.: 'I want that you should come to the movies with me tomorrow.' (Turkish; Kornfilt 1997: 46, ex. (199))
b. [ Yarin ben-im-le sinema-ya gel-me-n-i] tomorrow I-GEN.1SG-COM cinema-DAT come-INF-2SG-ACC ist-iyor-um. want-PROG-1SG 'I want you to come to the movies with me tomorrow.' lit.: 'I want your coming to the movies with me tomorrow.' (Turkish; Kornfilt 1997: 48, ex. (206))

Recent work, however, has shown that $k i$-clauses as in (61a) are licensed only when the matrix predicate is an assertive one (Kesici, 2013), which reveals a striking resemblance between PhG and Turkish. Differently than the analysis proposed here for PhG ki, however, Kesici (2013) (also Griffiths and Güneş 2015) argues that $k i$-clauses as in (61a) are parenthetical clauses and are not internal 
arguments of the matrix predicate. These authors, however, do not associate $k i$ with any modal function, contrary to the analysis proposed here for $\mathrm{PhG} k i$. Furthermore, Griffiths and Güneş (2015) extend their paratactic analysis of $k i$ for cases such as (61a) to certain other environments in which $k i$ is employed, such as appositive relatives (62a), emphatic clauses (62b) or temporal clauses $(62 c)$ :

(62) a. appositive relatives
Abi-m,
[ ki iş-i-ni
daima

brother-POss.1SG KI work-POss.3.SG-ACC always

zaman-ın-da yap-ar- Ø], bu sefer geciktir-miş- $\emptyset$.

time-POsS.3SG-LOC do-AOR-3SG this time delay-EV-3SG

'My brother, (he) always does his homework on time, handed it in late.'

b. emphatic clauses

O kadar gül-dü-k ki!

that much laugh-PST-1PL KI

'We laughed so much!'

c. temporal clauses

[ Güneş bat-mış-tı- $\emptyset$ ki] garip ses-ler duy-ma-ya sun set-EV-PST-3SG KI strange sound-PL hear-INF-DAT başla-dı-k.

start-PST-1PL

'The sun had set when we started to hear strange sounds.' (Turkish; Griffiths and Güneş 2015: 176-177, ex. $(9,12,13))$

Additionally, certain speaker oriented adverbs (which may also function as adjectives) can also be followed by ki in Turkish:

(63) Kuşkusuz/tabii/elbette

(ki) bizim takım kazan-acak- $\varnothing$. undoubted(ly)/naturally/certainly KI our team win-FUT-3SG 'Undoubtedly/definitely/certainly, ouw team will win.' (Turkish)

Cases such as (63) are not discussed in Kesici (2013) or Griffiths and Güneş (2015); therefore, it is not clear whether these authors' paratactic analysis also extends to (63) or not. More crucially, however, it remains to be seen whether all the ki-constructions in Turkish provided in (61a), (62) and (63) can also be accounted for uniformly by the same analysis as I proposed for $k i$-constructions in PhG. It should be noted here that, unlike the case in Turkish, $k i$ in PhG is not 
employed in appositive relatives or in temporal clauses. The reason why this is so should also be addressed in future research.

Another issue that is not addressed here but should be taken up in future research is whether the functions of PhG ki may also be associated with the functions of the Hellenic coordinator zai [ke] 'and', which began to be used as a subordinator as early as (at least) Post-classical Greek. Early examples involving $k e$ are generally cases of parataxis (Ljungvik 1932; Bentein 2015): ${ }^{27}$

(64) a. [...] îelon ke pémpse(=pémpsai) si ti állo [...] wanted.ISG and send.INF to.you something else

'... I also wanted to send you something else ...'

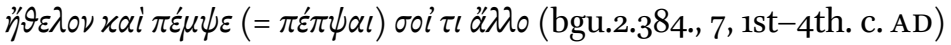

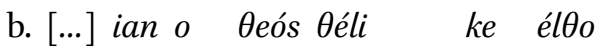

$[\cdots]$

if the God want.3SG and come.subJ.1SG

'... if God wants me to come ...'

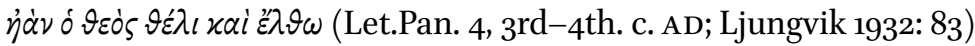

In Medieval Greek, $\varkappa$ a i is further observed to be used instead of the declarative complementizer ơ $\tau \iota$ (see especially Kriaras 1980: 217 ): 28

(65) a. Ipoptévasin ke Jiókun tous apopíso.

suspected.3PL and chase.3PL them from.behind

'They suspected that they chased after them.'

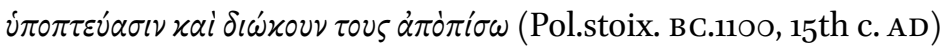

b. Os íkuse ke pnigiken eflívin $i$ oréa

When heard.3sg and drowned.3sg mourned.3sg the beauty

'When she [Chrysandza] heard that she [Faidrokaza] drowned, the beautiful girl mourned'

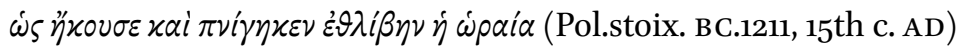

c. Jen éfnote ki o Érotas sixnía či katakrúi.

not knew.3sG and the love often her hurt.3SG

'He didn't know that Love often hurts her.'

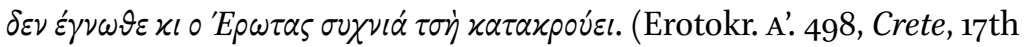
c. AD)

27 I am indebted to Delphine Nachtergaele for bringing example (64a) to my attention.

28 I am indebted to Jorie Soltic for providing me with the examples in $(65 a)-(65 b)$. 
In Modern Greek as well, $k e$ can replace declarative oti/pos, factive $p u$ and subjunctive $n a$ complementizers ((66a)-(66c) respectively). Roussou (2006) calls these paratactical constructions (for $k e$ in Modern Greek, see also Ingria 2005):

(66) a. I María árxise ki ékleye.

the Maria started.3sg and cried.3sG

'Mary started to cry.' (= (na) Modern Greek; Roussou 2006: 28, ex. (16ץ))

b. Tous iða ki ékleyan.

them saw.1SG and cried.3PL

'I saw them crying.' (= ( $p u)$ Modern Greek; Roussou 20o6: 28, ex. (16ס))

c. Oarís ke ine alitino.

suppose.2SG and is real

'You think it is real.' (= (oti/pos) Modern Greek; Roussou 2006: 28, ex. $(16 \varepsilon))$

Unfortunately, there is no systematic research on the interpretive nuances of constructions which involve $k i$ and which are provided in (64)-(66). Such a systematic analysis may also uncover how $k i$ has been associated with its functions in $\mathrm{PhG}$ today.

Finally, it has been observed at least since Dawkins (1910a: 128, §35 (3), 1910b: 283 , § 82) that homophonous ki's occur in two Asia Minor Greek dialects closely related to $\mathrm{PhG}$ as well, i.e., Cappadocian and Silliot dialects (see also Dawkins 1916: 685). Though I have not addressed these ki's here, I hope to have sparked further research on the similarities and differences between ki's in these three dialects.

\section{References}

Abels, Klaus. 2003. Successive cyclicity, anti-locality and adposition stranding. Doctoral Dissertation, University of Connecticut, Storrs.

Aelbrecht, Lobke. 2006. IP-ellipsis in Dutch dialects. $X+$ that-clause. Linguistics in the Netherlands 23:1-14.

Alexiadou, Artemis. 1997. Adverb placement: A case study in antisymmetric syntax. Amsterdam/Philadelphia: John Benjamins.

Anastasiadis, Vasilis. 1976. I sintaksi sto Pharasiotiko idioma tis Kappadokias [The syntax of the dialect of Pharasa in Cappadocia]. Doctoral Dissertation, University of Ioannina, Ioannina. 
Anastasiadis, Vasilis. 1980. Tourkikes leksis sto Pharasiotiko idioma [Turkish words in the dialect of Pharasa]. Deltio Kentrou Mikrasiatikon Spoudon 2:33-120.

Andriotis, Nikolaos P. 1948. To glossiko idioma ton Pharason [the dialect of Pharasa]. Athens: Ikaros.

Bağnaçı, Metin. in preparation. Pharasiot Greek: Word order and clause structure. Doctoral Dissertation, Ghent University, Belgium.

Bennis, Hans. 1987. Gaps and dummies, Vol. 9 of Linguistic Models. Dordrecht: Foris.

Bentein, Klaas. 2015. Minor complementation patterns in Post-classical Greek (IVI AD). A socio-historical analysis of a corpus of documentary papyri. Symbolae Osloenses 89:104-147.

Chafe, Wallace. 1986. Evidentiality in English conversation and academic writing. In Evidentiality: The linguistic coding of epistemology, ed. Wallace Chafe and Johanna Nichols, Vol. 20 of Advances in Discourse Processes, 261-272. Norwood, NJ: Ablex.

Cinque, Guglielmo. 1999. Adverbs and functional heads. A cross-linguistic perspective. Oxford Studies in Comparative Syntax. Oxford and NY: Oxford University Press.

Collins, Chris, and Phil Branigan. 1997. Quotative inversion. Natural Language and Linguistic Theory 15:1-41.

Cruschina, Silvio. 2015. The expression of evidentiality and epistemicity: Cases of grammaticalization in Italian and Sicilian. Probus 27:1-31.

Dawkins, Richard McGillivray. 1910a. Modern Greek in Asia Minor. The Journal of Hellenic Studies 30:109-132.

Dawkins, Richard McGillivray. 191ob. Modern Greek in Asia Minor (continued). The Journal of Hellenic Studies 30:267-291.

Dawkins, Richard McGillivray. 1916. Modern Greek in Asia Minor: A study of the dialects of Sili, Cappadocia and Phárasa, with grammar, texts, translation and glossary. Cambridge, uk: Cambridge University Press.

Dawkins, Richard McGillivray. 1937. The Pontic dialect of Modern Greek in Asia Minor and Russia. Transactions of the Philological Society 36:15-52.

Dawkins, Richard McGillivray. 1955. The boy's dream. Mikrasiatika Xronika 18:4189 .

Di Sciullo, Anna Maria, and Edwin Williams. 1987. On the definition of word. Cambridge, MA: MIT Press.

Drettas, Georges. 200o. Marques de focus en grec commun et en pontique. Studies in Greek Linguistics. Proceedings of the 2oth Annual Meeting of the Department of Linguistics, Faculty of Philosophy, Aristotle University of Thessaloniki, April 23-25, 1999: 122-131.

Erguvanl, Emine Eser. 1980-1981. A case of syntactic change: Ki constructions in Turkish. Boğaziçi Üniversitesi Dergisi, Humanities 8-9:111-139.

Ernst, Thomas. 2002. The syntax of adjuncts, Vol. 96 of Cambridge Studies in Linguistics. Cambridge, u K: Cambridge University Press. 
Giannakidou, Anastasia. 1998. Polarity sensitivity as (non)veridical dependency, Vol. 23 of Linguistik Aktuell/Linguistics Today. Amsterdam/Philadelphia: John Benjamins.

Giannakidou, Anastasia. 20og. The dependency of the subjunctive revisited: Temporal semantics and polarity. Lingua 119:1883-19o8.

Giorgi, Alessandra. 2010. About the speaker: Towards a syntax of indexicality, Vol. 28 of Oxford Studies in Theoretical Linguistics. Oxford and NY: Oxford University Press.

Gordon, Lynn. 1986. The development of evidentials in Maricopa. In Evidentiality: The linguistic coding of epistemology, ed. Wallace Chafe and Johanna Nichols, Vol. 20 of Advances in Dicourse Processes, 75-88. Norwood, NJ: Ablex.

Grange, Corinne, and Liliane Haegeman. 1989. Subordinate clauses: Adjuncts or arguments-the status of het in Dutch. In Sentential complementation and the lexicon: Studies in honour of Wim de Geest, ed. Dany Jaspers, Wim Klooster, Yvan Putseys, and Pieter Seuren, Linguistic Models, 155-171. Dordrecht: Foris.

Grégoire, Henri. 1909. Appendice: Notes sur le dialecte de Farasha. Bulletin de Correspondance hellénique 33:148-159.

Griffiths, James, and Güliz Güneş. 2015. Ki issues in Turkish: Parenthetical coordination and adjunction. In Parenthesis and ellipsis: Cross-linguistic and theoretical perspectives, ed. Marlies Kluck, Dennis Ott, and Mark de Vries, Vol. 121 of Studies in Generative Grammar, 173-218. Berlin: Mouton de Gruyter.

Grohmann, Kleanthes K. 2003. Prolific Domains: On the Anti-Locality of movement dependencies, Vol. 66 of Linguistik Aktuell/Linguistics Today. Amsterdam/Philadelphia: John Benjamins.

Gussenhoven, Carlos. 2007. Types of focus in English. In Topic and focus. Cross-linguistic perspectives on meaning and intonation, ed. Chungmin Lee, Matthew Gordon, and Daniel Büring, Vol. 82 of Studies in Linguistics and Philosophy, 83-10o. Dordrecht: Springer.

Haddican, Bill, Anders Holmberg, Hidekazu Tanaka, and George Tsoulas. 2014. Interrogative slifting in English. Lingua 138:86-106.

Haegeman, Liliane. 2002. Anchoring to speaker, adverbial clauses and the structure of CP. Georgetown University Working Papers in Theoretical Linguistics 2:117-180.

Haegeman, Liliane. 2012. Adverbial clauses, main clause phenomena, and composition of the left periphery, The cartography of syntactic structures 8. Oxford Studies in Comparative Syntax. Oxford and NY: Oxford University Press.

Haegeman, Liliane. 2014. West flemish verb-based discourse markers and the articulation of the Speech Act layer. Studia Linguistica 68:116-139.

Haegeman, Liliane, and Virginia Hill. 2013. The syntacticization of discourse. In Syntax and its limits, ed. Raffaella Folli, Christina Sevdali, and Robert Truswell, Vol. 48 of Oxford Studies in Theoretical Linguistics, 370-390. Oxford and NY: Oxford University Press.

Hill, Virginia. 2007. Romanian adverb and the pragmatic field. The Linguistic Review 24:61-86. 
Hill, Virginia. 2010. Declarative root clauses with 'That'. In Interfaces in language, ed. John Partridge, 57-69. Newcastle-upon-Tyne: Cambridge Scholars Publishing.

Hill, Virginia. 2012. A main clause complementizer. In Main clause phenomena: New horizons, ed. Lobke Aelbrecht, Liliane Haegeman, and Rachel Nye, Vol. 190 of Linguistik Aktuell/Linguistics Today, 279-295. Amsterdam/Philadelphia: John Benjamins.

Hooper, Joan B. 1975. On assertive predicates. In Syntax and semantics, vol. 4, ed. John P. Kimball, 91-124. NY: Academic Press.

Hooper, Joan B., and Sandra A. Thompson. 1973. On the applicability of root transformations. Linguistic Inquiry 4:465-497.

Ingria, Robert J. 2005. Grammatical formatives in a generative lexical theory: The case of Modern Greek xal. Journal of Greek Linguistics 6:61-101.

Jackendoff, Ray. 1972. Semantic interpretation in Generative Grammar. Cambridge, MA: Mit Press.

Janse, Mark. 1998. Cappadocian clitics and the syntax-morphology interface. In Themes in Greek linguistics 2, ed. Brian D. Joseph, Geoffrey C. Horrocks, and Irene PhilippakiWarburton, 257-281. Amsterdam/Philadelphia: John Benjamins.

Janse, Mark. 2001. Morphological borrowing in Asia Minor Greek. In Proceedings of the 4th international conference on Greek linguistics, ed. Georgia Aggouraki, Amalia Arvaniti, J.I.M. Davy, Dionysios Goutsos, Marilena Karyolaimou, Anna Panagiotou, Andreas Papapavlou, Pavlos Pavlou, and Anna Roussou, 473-479. Thessaloniki: University Studio Press.

Johanson, Lars. 1996. Kopierte Satzjunktoren im Türkischen. sTUF-Language Typology and Universals 49:39-49.

Karatsareas, Petros. 2011. A study of Cappadocian Greek nominal morphology from a diachronic and dialectological perspective. Doctoral Dissertation, University of Cambridge, Cambridge, uk.

Karttunen, Lauri. 1971. Some observations on factivity. Papers in Linguistics 4:55-69.

Kayne, Richard. 1994. The antisymmetry of syntax. Cambridge, MA: MIT Press.

Kesici, Esra. 2013. Ki-clauses in Turkish: A paratactic analysis. Coyote Papers: Working Papers in Linguistics 21. Available online at http://hdl.handle.net/1015o/271012.

Kiparsky, Paul, and Carol Kiparsky. 1970. Fact. In Progress in linguistics, ed. Manfred Bierwisch and Karl Eric Heidolph, 143-173. The Hague: Mouton.

Kornfilt, Jaklin. 1997. Turkish. London and New York: Routledge.

Kriaras, Emmanuel. 1980. Leksiko tis Meseonikis Ellinikis dimodus grammatias-110o1669 [Dictionary of Medieval Greek vernacular register-110o-1669], vol. 6. Thessaloniki: Center for Greek Language.

Kroch, Antony. 1989. Reflexes of grammar in patterns of language change. Language Variation and Change 1:199-244.

Kyrillos, Patriarch VI of Constantinople. 1815. Istoriki perigrafi tou en Vienni proek- 
dothentos chorografikou pinakos tis megalis Archisatrapias Ikoniou, nin proton tipois ekdothisa [A historical account of the topographical table of the Greater Archisatrapia of Iconium, published formerly in Vienna, now formally published for the first time]. Constantinople: Patriarchikón Tipografeíon.

Levidis, Anastasios. 1892. Pragmatia peri tis en Kappadokia lalumenis glossis ipo Anastasiu M. Levidu meta ton dimodon asmaton, enigmaton, parimion, efchon, kataron, orkon, kirion onomaton, mithon, asmaton meseonikon, grammatikis, ke glossarion okto, ke simioseon [A treatise by A.M. Levidis on the language spoken in Cappadocia, with vernacular songs, riddles, wishes, curses, oaths, proper names, fables, medieval songs, grammar and glossary, and notes]. Manuscript deposited at Centre of Asia Minor Greek Studies (partly published).

Ljungvik, Herman. 1932. Beiträge zur Syntax der spätgriechischen Volkssprache, Vol. 27 of Skrifter Utgivna av K. Humanistiska Vetenskaps-Samfundet i Uppsala. Uppsala: Almqvist \& Wiksells Boktrycheri.

Lyons, John. 1977. Semantics, vol. 2. Cambridge, u K: Cambridge University Press.

Miyagawa, Shigeru. 2012. Agreements that occur mainly in the main clause. In Main clause phenomena: New horizons, ed. Lobke Aelbrecht, Liliane Haegeman, and Rachel Nye, Vol. 19 o of LinguistikAktuell/Linguistics Today, 79-112. Amsterdam/Philadelphia:John Benjamins.

Palmer, Frank Robert. 1986. Mood and modality. Cambridge Textbooks in Linguistics. Cambridge, uk: Cambridge University Press.

Papadopoulos, Iordanis V. 1998. I Pharasiotes apo to Roum nachiesi tis Kappadokias sto Roumlouki tis Makedonias [The Pharasiot Greeks from the district of Rum to Rumluk of Macedonia]. Dimorama 3:45-50.

Papadopoulos, Iordanis V. 2011. Kappadhokika paramathia ke laikes paradosis: Farasa, Silli, Aravan, Ghurduno [Cappadocian stories and lore: Pharasa, Silli, Aravan and Ghourzono]. Athens: KE.MI.PO.

Ramat, Paolo, and Davide Ricca. 1998. Sentence adverbs in the languages of Europe. In Adverbial constructions in the languages of Europe, ed. Johan van der Auwera, 187277. Berlin: Mouton de Gruyter.

Revithiadou, Anthi, Marc van Oostendorp, Kalomoira Nikolou, and Marianna Tiliopoulou. 2006. Vowel harmony in contact-induced systems: The case of Asia Minor dialects of Greek. In Proceedings of the 2nd international conference of Modern Greek dialects and linguistic theory, September 30-October 3, 2004, Mytilene, ed. Mark Janse, Brian D. Joseph, and Angela Ralli, 350-365. Patras: University of Patras.

Rizzi, Luigi. 1997. The fine structure of the left periphery. In Elements of grammar, ed. Liliane Haegeman, 281-337. Dordrecht: Kluwer.

Rizzi, Luigi. 2004. Locality and left periphery. In Structures and beyond: The cartography of syntactic structures, vol. 3, ed. Adriana Belletti, 223-251. Oxford and NY: Oxford University Press. 
Rizzi, Luigi, and Guglielmo Cinque. 2016. Functional categories and syntactic theory. Annual Review of Linguistics 2:139-163.

Rooryck, Johan. 2001. Evidentiality, part 1. Glot International 5:125-133.

Ross, John Robert. 1967. Constraints on variables in syntax. Doctoral Dissertation, MIT, Cambridge, MA. Published as Infinite Syntax, Norwood, N.J.: Ablex, 1986.

Roussou, Anna. 2000. On the left periphery: Modal particles and complementisers. Journal of Greek Linguistics 1:65-94.

Roussou, Anna. 2006. Simpliromatiki diktes [Complementizers]. Athens: Patakis.

Roussou, Anna, and Anastasios Tsangalidis. 2010. Reconsidering the 'modal particles' in Modern Greek. Journal of Greek Linguistics 10:45-73.

Russell, Bertrand. 1954 [1927]. The analysis of matter. London: George Allen and Unwin Ltd.

Sarantidis, Archelaos I. 1899. I Sinasos [Sinasos]. Athinai: Tipografeion Ioannou Nikolaïdou.

Sitaridou, Ioanna, and Maria Kaltsa. 2014. Contrastivity in Pontic Greek. Lingua 146:127.

Speas, Margaret. 2004. Evidentiality, logophoricity and the syntactic representation of pragmatic features. Lingua 114:255-276.

Speas, Margaret, and Carol Tenny. 2003. Configurational properties of point of view roles. In Asymmetry in grammar, ed. Anna Maria Di Sciullo, 315-343. Amsterdam/ Philadelphia:John Benjamins.

Sperber, Dan, Fabrice Clément, Christophe Heintz, Olivier Mascaro, Hugo Mercier, Gloria Origgi, and Deirdre Wilson. 2010. Epistemic vigilance. Mind \& Language 25:359-393.

Suñer, Margarita. 1993. About indirect questions and semi-questions. Linguistics and Philosophy 16:45-77.

Suñer, Margarita. 2000. The syntax of direct quotes with special reference to Spanish and English. Natural Language and Linguistic Theory 18:525-578.

Tenny, Carol. 2006. Evidentiality, experiences, and the syntax of sentence in Japanese. Journal of East Asian Linguistics 15:245-288.

Theodoridis, Theodoros. 1939. Diorthosi kimenou ke scholia paramithion farasiotikon, R. Dawkins [Corrections of the Pharasiot texts and comments on the stories by R. Dawkins]. Unpublished Manuscript.

Theodoridis, Theodoros. 1964. Pharasiotikes paradosis, mithi kai paramithia 2 [Pharasiot customs, myths and stories 2]. Laografia:Deltion tis Ellinikis Laografikis Etaireias 21:209-336.

Theodoridis, Theodoros. 1966. Pharasiotikos istorikos dialogos [A historical dialogue in Pharasiot]. Unpublished Manuscript, deposited at the Center of Asia Minor Studies, Athens.

de Vries, Mark. 2006. Reported direct speech in Dutch. Linguistics in the Netherlands $23: 212-223$. 
Willett, Thomas. 1988. A crosslinguistic survey of the grammaticization of evidentiality. Studies in Language 12:51-97.

Wilson, Deirdre. 2011. The conceptual-procedural distinction: Past, present and future. In Procedural meaning: Problems and perspectives, ed. Victoria Escandell-Vidal, Manuel Leonetti, and Aoife Ahern, Vol. 25 of Current Research in the Semantics/Pragmatics Interface, 3-31. Bingley, U K: Emerald Groups Publishing.

Xenofanis. 1896, 1905-1910. Xenofanis, singramma periodikon tu sillogou Mikrasiaton, "Anatolis" [Xenophanes, collection of the magazine "Anatoli" of the society of Asia Minor Greeks], vol. i, ii-vii. Athens: Paraskeva Leoni.

Zurnatzis, Thodoris. 195os. Viografiko. Unpublished Manuscript deposited at the Center of Asia Minor Studies. 